\title{
Molecular Basis of Neuronal Autophagy in Ageing: Insights from Caenorhabditis elegans
}

\author{
Georgios Konstantinidis ${ }^{1}$ (D) and Nektarios Tavernarakis $1,2, *$ (D) \\ 1 Institute of Molecular Biology and Biotechnology, Foundation for Research and Technology-Hellas, \\ 70013 Heraklion, Greece; georgios_konstantinidis@imbb.forth.gr \\ 2 Department of Basic Sciences, School of Medicine, University of Crete, 70013 Heraklion, Greece \\ * Correspondence: tavernarakis@imbb.forth.gr
}

check for updates

Citation: Konstantinidis, G.;

Tavernarakis, N. Molecular Basis of Neuronal Autophagy in Ageing: Insights from Caenorhabditis elegans. Cells 2021, 10, 694. https://doi.org/ 10.3390/cells10030694

Academic Editors: Christiaan Leeuwenburgh and Anna Picca

Received: 28 February 2021

Accepted: 18 March 2021

Published: 21 March 2021

Publisher's Note: MDPI stays neutral with regard to jurisdictional claims in published maps and institutional affiliations.

Copyright: (c) 2021 by the authors. Licensee MDPI, Basel, Switzerland. This article is an open access article distributed under the terms and conditions of the Creative Commons Attribution (CC BY) license (https:// creativecommons.org/licenses/by/ $4.0 /)$.

\begin{abstract}
Autophagy is an evolutionarily conserved degradation process maintaining cell homeostasis. Induction of autophagy is triggered as a response to a broad range of cellular stress conditions, such as nutrient deprivation, protein aggregation, organelle damage and pathogen invasion. Macroautophagy involves the sequestration of cytoplasmic contents in a double-membrane organelle referred to as the autophagosome with subsequent degradation of its contents upon delivery to lysosomes. Autophagy plays critical roles in development, maintenance and survival of distinct cell populations including neurons. Consequently, age-dependent decline in autophagy predisposes animals for age-related diseases including neurodegeneration and compromises healthspan and longevity. In this review, we summarize recent advances in our understanding of the role of neuronal autophagy in ageing, focusing on studies in the nematode Caenorhabditis elegans.
\end{abstract}

Keywords: ageing; autophagy; Caenorhabditis elegans; neurodegeneration; macroautophagy; neuronal autophagy

\section{Introduction \\ 1.1. Mechanisms of Autophagy}

Autophagy is an evolutionarily conserved process enabling cells to regulate a plethora of catabolic needs. Under physiological conditions, autophagy serves as a quality control mechanism in order to maintain cell homeostasis. Importantly, in response to extracellular or intracellular stress, autophagy is employed to degrade and recycle macromolecules such as misfolded or aggregated proteins as well as to eliminate dysfunctional organelles or invading pathogens [1-3]. Macroautophagy, microautophagy and CMA (chaperonemediated autophagy) are the three morphologically and mechanistically distinct types of autophagy. However, all three converge towards the delivery of cargo to the lysosome for degradation.

In microautophagy, cytoplasmic components enter the lysosome through a direct invagination of the lysosomal limiting membrane. Membrane fission results to the release of a microautophagic body into the organelle lumen for degradation [4]. CMA involves the selective recognition of a substrate based on the KFERQ-like motif by a cytosolic chaperone, the HSC70 (heat shock cognate $71 \mathrm{kDa}$ protein) and cochaperones [5]. Subsequently, unfolding of the substrate and translocation via the receptor LAMP2A (lysosome-associated membrane protein type 2A) leads to the degradation of the substrate.

Macroautophagy (hereafter referred to as autophagy), is a process that enables cells to recycle and degrade intracellular contents. Hallmark of autophagy is the de novo formation of a double-membrane vesicle, termed the autophagosome, which sequesters and engulfs cytoplasmic material (Figure 1A). Subsequently, autophagosome matures and fuses with a lysosome to form an autolysosome, leading to the exposure of the autophagic cargo to the lysosomal hydrolases for digestion [6-8]. Autophagosome formation is driven by the orchestrated action of approximately 20 ATG (autophagy-related) proteins, 
whose role is essential for autophagic delivery of cargo to the lysosome or vacuole in yeast (Figure 1B,C) [9-13]. Nutrient and energy sensing pathway hubs, including mTOR (mechanistic target of rapamycin) and AMPK (AMP-activated protein kinase), converge to the ULK1 (Unc-51-like kinase 1) complex [ULK1, ATG13, FIP200/RB1CC1 (200 kDa FAK family kinase-interacting protein/RB1-inducible coiled-coil protein 1) and ATG101] for autophagy initiation (Figure 1B). ULK1 complex triggers the nucleation of an autophagosome membrane precursor, termed isolation membrane or phagophore by phosphorylating members of the PI3KC3 (class III phosphatidylinositol-3 kinase) complex I [VPS34 (vacuolar protein sorting 34), Beclin 1, ATG14, AMBRA1 (activating molecule in Beclin 1-regulated autophagy protein 1) and general vesicular transport factor (p115)]. PI3KC3 complex I induces the local production of PI3P (phosphatidylinositol-3-phosphate) at a characteristic endoplasmic reticulum structure called the omegasome. Two PI3P effector proteins the WIPI2 (WD repeat domain, phosphoinositide interacting 2) and the DFCP1 (zinc-finger double FYVE-containing protein 1) are recruited to the omegasome via interaction with their PI3P-binding domains. Locally accumulated WIPI2 directly binds and recruits ATG12 (ATG12-ATG5-ATG16L1) complex and catalyzes the conjugation of the C-terminal glycine of ATG8 family proteins, [including LC3 (microtubule-associated protein light chain 3) and GABARAP ( $\gamma$-aminobutyric acid receptor-associated protein)] to the phagophore-resident lipid PE (phosphatidylethanolamine) (Figure 1C). The lipidated, thus membrane-bound LC3 (called LC3-II), characteristic signature of autophagic membranes, is required for elongation and closure of the phagophore. ATG4, the sole ATG protease, processes nascent ATG8 to expose the C-terminal glycine residue [14]. ATG8 protein family members interact with autophagy receptor proteins or SARs (selective autophagy receptors) bearing LIRs (LC3-interacting regions) in order to sequester the cytoplasmic material destined for lysosomal degradation [15]. The endoplasmic reticulum (ER) and the majority of cellular membranes have been proposed to contribute membrane material for the elongation of the autophagosomal membrane [16,17]. ATG2 mediates phospholipid transfer from ER or other donor membrane sources to an ATG9-positive vesicle/phagophore. ATG9, the sole transmembrane ATG protein possesses membrane-bending properties. It facilitates autophagosomal membrane expansion acting as a scramblase. Specifically, ATG9 transports phospholipids from the cytoplasmic to the luminal leaflet of the isolation membrane [18-22]. ESCRT (endosomal sorting complexes required for transport) machinery facilitates phagophore closure, a process involving membrane fission of the inner and outer membrane at the phagophore edge [23,24]. After phagophore closure, the complete autophagosome undergoes maturation by dissociation or removal of most ATG proteins, including ATG8 by ATG4 protease, as well as PI3P by MTMR (myotubularinrelated) phospholipid phosphatase from the autophagosome surface [25]. ATG8 family members, tethering factors, Rab (Ras-associated binding) GTPases, and SNARE (soluble $\mathrm{N}$-ethylmaleimide-sensitive factor-attachment protein receptor) proteins act in concert to mediate fusion of autophagosomes with lysosomes [26]. Finally, the lysosomal acidic hydrolases digest the sequestered autophagic cargo and salvaged building blocks including amino acids, fatty acids, nucleotides and sugars are recycled back to the cytoplasm in order to be used again by the cell. 

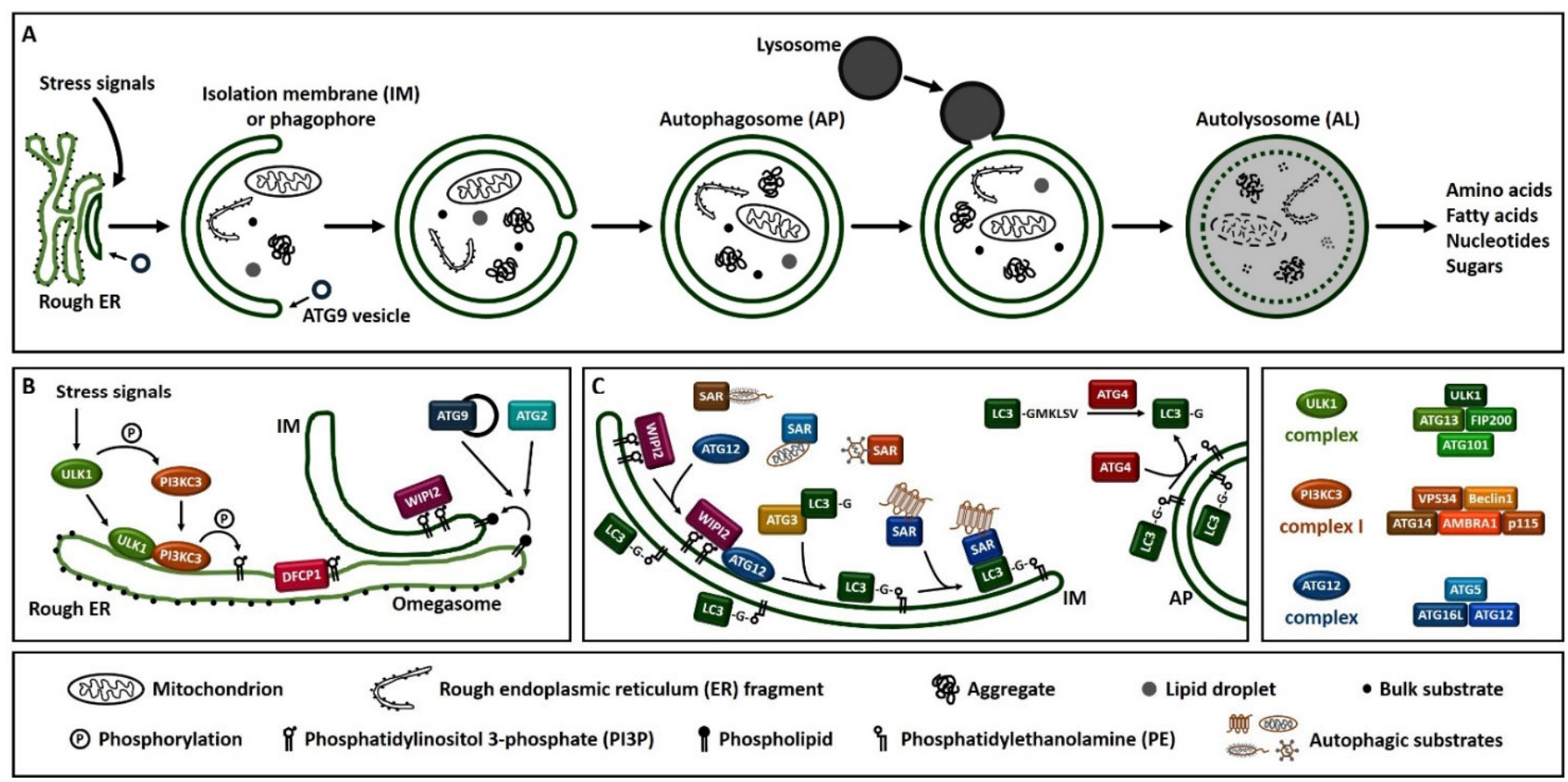

Figure 1. Overview of the autophagy process in human. (A). Schematic representation of autophagosome formation and cargo degradation. Complete autophagosomes may fuse with endosomes to form amphisomes, which further fuse with lysosomes. (B). Omegasome and isolation membrane generation. (C). Isolation membrane expansion, LC3 processing and autophagic substrate sequestration. Additional membrane sources may contribute to isolation membrane formation and expansion. SAR: selective autophagy receptor, LC3-GKLSV: pro-LC3, LC3-G: LC3-I, LC3-G-PE: LC3-II.

Autophagy is considered to have primarily cytoprotective and pro-survival functions. Therefore, as a critical cellular process it needs to be tightly regulated in order to respond and adapt appropriately to various cellular stress signals and insults. Several mutations in ATG genes have been identified and associated with human genetic disorders, developmental abnormalities, immune diseases, cancer and neurodegeneration, demonstrating a role for autophagy in animal health $[27,28]$.

\subsection{Neuronal Autophagy}

As anticipated, autophagy is indispensable for neuronal survival and maintenance of neuron homeostasis. Genetic studies have demonstrated that conditional ablation of the core autophagy genes atg5 and $\operatorname{atg} 7$ in the nervous system of mice leads to accumulation of ubiquitin-containing inclusion bodies disrupting neuronal function and causing progressive neurodegeneration $[29,30]$. Autophagy in hypothalamic neurons is required specifically for the regulation of nutrient uptake, energy balance, obesity as well as ageing [31-34]. Hippocampal neurons of fragile X syndrome mice model exhibit reduced levels of autophagy. Activation of autophagy partially rescues the aberrant dendritic spine morphology, mGluR-LTD (metabotropic glutamate receptor-dependent long-term depression) and cognition in those mice [35]. Knockout studies have demonstrated an essential role for autophagy in embryonic neurogenesis and mutations in autophagy genes lead to developmental delay, cognitive decline, and functional deficits in childhood [36-49]. In addition, autophagy plays a role in the differentiation of adult NSCs (neuronal stem cells) [50-57]. Furthermore, specific processes involved in neuronal plasticity such as axonal growth, synaptic assembly, and dendritic spine formation and pruning are linked to autophagic activity and accompanied by cognitive deficits, anxiety-like behaviors, autism-like behaviors and memory deficits [35,58-65]. Given the contribution of autophagy in neurogenesis and neuronal plasticity, it is apparent that pharmacological or genetic induction of autophagy might be a means of treatment and therapy for disorders like depression, bipolar disorder, 
and schizophrenia [66-77]. In contrast, the lysosomal acidification inhibitor bafilomycin A1, which blocks autophagosome-lysosome fusion and therefore autophagic flux, has antidepressant effects in rats exposed to chronic unpredictable mild stress [78]. In that case, autophagy inhibition seems to be advantageous.

Neurons possess unique structural and functional characteristics. Cellular processes have to be tightly and differentially regulated in a spatiotemporal manner. For example, neuronal soma is often located far away from the synapses. Therefore, specialized processes restricted to the microenvironment of the synapse ensure proper synaptic transmission. Synaptic activity has been linked to autophagy in molecular and vesicular level [61,79-85]. Constitutive de novo autophagosome biogenesis occurs at the axon terminal and upon completion, autophagosomes fuse with late endosomes and/or lysosomes. In distal axons of primary DRG (dorsal root ganglion) neurons, autophagosomes seem to be generated at DFCP1-positive subdomains of the endoplasmic reticulum, distinct from ER exit sites [86]. Moreover, plasma- or mitochondrial-derived membranes were not incorporated into nascent autophagosomes. A minor population appears to arise from pre-existing autophagosome rings. The authors suggest that autophagosome rings may sometimes nucleate other smaller autophagic structures. Subsequently, autophagosomes are transported along the axonal microtubules toward the soma, in a dynein-dependent manner [87-92]. In transit, they fuse with additional lysosomes, arriving at the soma as fully competent degradative organelles. In general, autophagosome biogenesis events are enriched distally. However, autophagosomes form infrequently in dendrites, the soma, or midaxon [86].

Presynaptic autophagosomes engulf synaptic vesicles and therefore autophagy regulates neurotransmission by controlling the pool of the synaptic vesicles and neurotransmitter release [60,79]. Pharmacological activation of autophagy reduces the number of synaptic vesicles. Loss of autophagy increases evoked dopamine release in mice. BDNF (brain-derived neurotrophic factor) stimulates retrograde motility of autophagic compartments positive for the receptor of BDNF, TrkB (tropomyosin receptor kinase B) [93]. The phosphorylated endocytic adaptor endophillin $\mathrm{A}$ is enriched at the presynaptic terminals and promotes autophagy by generating highly curved membranes, where core autophagy proteins are recruited to form autophagosomes $[82,83]$. The lipid phosphatase synaptojanin 1 , implicated in synaptic vesicle trafficking, is also required for autophagosome biogenesis at presynaptic terminals [61]. The scaffolding protein bassoon, localized to the presynaptic nerve terminals as well, sequesters ATG5 and inhibits presynaptic autophagy [60]. Mitophagy targets ubiquitinated mitochondria in synapses; thereby it may regulate local energy supply or calcium buffering capacity [94].

Predominant destination for autolysosome cargo degradation is the cell body, where lysosomes with high proteolytic activity reside $[95,96]$. Inhibition of lysosomal activity leads to accumulation of autophagosomes specifically within the soma, and not in the axon or dendrites [97]. Sequestration of mitochondria fragments have been captured into a subpopulation of autophagosomes [98]. Interestingly, an alternative mechanism for eliminating protein aggregates and mitochondria when autophagy is compromised is the secretion of large vesicles called exophers by several neuronal cell types, including dopaminergic and sensory neurons [99,100]. Extruded exophers are engulfed by neighboring cells for lysosomal degradation or released into the extracellular milieu. These finding suggest that neuronal cells do not necessarily degrade their own aggregates or damaged organelles, introducing a possible mechanism for the prion-like propagation phenomenon. From a pharmacological point of view, on one hand, induction of the release of toxic cargo outside of the cells will probably relieve the neurons from toxic loads but increase the propagation of prion-like pathologies. On the other hand, inhibition of the jettison of aggregates or damaged organelles, will probably prevent the pathology from spreading but will increase the toxic load into the neurons with possible detrimental consequences.

Postsynaptic autophagy plays a role in synaptic plasticity and synaptic strength, which are fundamental processes underling learning and memory [101-104]. Deletion of WDR45 (WD repeat domain 45) protein at the central nervous system leads to deficits in 
learning and memory in mice [105]. In LTP (long-term potentiation), low-dose activation of NMDARs ( $N$-methyl-D-aspartate receptors) leads to an increase in AMPAR ( $\alpha$-amino-3hydroxy-5-methyl-4-isoxazolepropionic acid receptor) internalization [106]. Conversely, in LTD (long-term depression), activation of NMDARs results in AMPARs degradation in hippocampal neurons. BDNF suppresses autophagy in cortical and hippocampal neurons, facilitating LTP and the persistence of memories in mice through stabilization of the postsynaptic scaffold proteins PICK1 (protein interacting with C kinase 1), PSD-95 (postsynaptic density protein 95) and SHANK3 (SH3 and multiple ankyrin repeat domains 3) [107]. Upon denervation of neuromuscular junctions, $\mathrm{GABA}_{\mathrm{A}} \mathrm{Rs}$ (gamma-aminobutyric acid type $\mathrm{A}$ receptors) are selectively sorted via endocytosis from the postsynaptic membrane of muscle cells to autophagosomes, whereas acetylcholine receptors in the same cells do not localize in autophagosomes [108].

Interestingly, non-canonical roles of autophagic machinery and ATG proteins have been linked to neuronal biology. ATG16L localizes on hormone-containing dense-core vesicles through interaction with RAB33 and participates in hormone secretion from neuroendocrine PC12 cells independently of its role in autophagy through RAB33 $[109,110]$. LANDO (LC3-associated endocytosis) regulates amyloid- $\beta$ clearance in microglia [111]. The inflammatory cytokine IL-1 $\beta$ (interleukin- $1 \beta$ ) is secreted via an unconventional autophagymediated secretory pathway in human neutrophils [112].

In conclusion, accumulating evidence support the prominent role of autophagy in the regulation of a wide range of cellular functions in neurons which are further translated in behavioral outputs $[85,113]$.

\subsection{Autophagy in Ageing}

Ageing, the time-dependent decline in cellular, tissue and organismal functions occurs in all metazoan organisms. Genetics play fundamental role in controlling ageing [114]. Numerous mutations that either extend lifespan or accelerate age-related decline have been characterized. Studies in those mutated genes revealed specific signaling pathways and cellular machineries conserved among species that regulate ageing. Accumulating evidence supports autophagy as a critical regulator of lifespan $[115,116]$. Caloric restriction and mTOR inhibition, two interventions known to extend lifespan, induce autophagy [116]. Autophagic activity and efficiency declines with age in diverse organisms. From C. elegans and rats to primary human cells, ageing reduces the capacity of lysosomal proteolysis compared to their younger counterparts $[117,118]$. Reduced expression of several ATG genes upon ageing is documented in several organisms including Drosophila and rodents [119-121]. In Drosophila, loss-of-function mutations of Atg7 and Atg8 genes reduce lifespan, increase sensitivity to stress and promote neuronal accumulation of ubiquitinpositive aggregates $[119,122]$. Mice exhibit an age-dependent decrease in autophagosome numbers [123]. In addition, genes important for autophagosome-lysosome fusion such as $L A M P 2$, show reduced expression upon ageing [124]. In human brain, ATG5, ATG7 and $B E C N 1$ are down-regulated during normal ageing [125]. Individuals with age-associated neurodegeneration diseases possess autophagy gene polymorphisms and exhibit reduced autophagy [126-129]. Since impairment of autophagy predisposes organisms to age-related diseases, such as neurodegeneration, genetic or pharmacological restoration of autophagy may be utilized for improving ageing-related diseases [115].

Oxidative stress, DNA damage, telomere shortening and inflammation play prominent causative role in ageing [130-133]. These factors can compromise cellular proteostatic mechanisms such as autophagy and contribute to the development or progression of agerelated neurodegenerative disorders, such as Alzheimer's, Huntington's or Parkinson's disease, and amyotrophic lateral sclerosis [134-138].

Research at the interface of autophagy and ageing highlights interesting and elegant aspects of this interplay [139]. Lifespan extension can be achieved with tissue-specific overexpression of a single atg gene, revealing the minimum intervention with sufficient effect in organismal level. Furthermore, autophagy stimulation in a select tissue can have 
systemic effects and influence ageing in a cell-non-autonomous manner. Finally, targeting and clearance of specific dysfunctional components via selective types of autophagy may be sufficient for longevity, highlighting the importance of selectivity and avoidance of excessive off-target energy-consuming autophagic activity. Focusing on research in the nematode C. elegans, we summarize recent advances in our understanding of the role of general and selective neuronal autophagy modulation in neuroprotection as well lifespan and healthspan regulation.

\section{Autophagy and Ageing in Caenorhabditis elegans}

\subsection{Caenorhabditis elegans as a Model Organism}

C. elegans, a self-fertilizing hermaphrodite nematode species, was the first multicellular organism with a complete genome sequence [140]. 60-80\% of C. elegans genes have human homologues [141]. The ease of genetic manipulation have led to the molecular identification of many key genes in developmental and cell biological processes [142]. A tremendous number of advantages such as small size, large brood populations, rapid life cycle, ease of cultivation, low maintenance expense, long-term cryopreservation, invariant cell number and development, transparency, and the ability to reduce gene activity using feeding RNAi render C. elegans an outstanding experimental system [143]. Primarily ethical concerns and secondarily human life expectancy and feasibility direct research to non-human model organisms [144]. Due to relatively short life expectancy, a wide range of biological processes can be easily assessed during the whole life span of the organism. In order to study the role and function of a specific protein of interest and further model the phenotype deriving from a human disease, researchers either mutagenize the respective homologue gene or overexpress the human gene implicating in the disease ubiquitously or in a specific tissue of C. elegans $[145,146]$. Expression of specific human proteins linked to neurodegeneration (e.g., $\alpha$-synuclein, amyloid- $\beta$ peptide or tau) leads to cellular toxicity in worms and flies. At least to some extent, invertebrate systems give the potential to generate important findings regarding mechanisms of neurotoxicity, which are extended in research in mammalian systems. Noteworthy, C. elegans nervous system structure and connectome is fully characterized, providing the most complete wiring reconstitution of any nervous system [147-149].

No perfect model organism exists to absolutely mimic human biology. Despite the high degree of conservation, there is still evolutionary distance between C. elegans and humans. Some mammalian genes have no homologs in the nematode (for example genes in the regulatory cascade of Hedgehog signaling) [150]. Furthermore, physiologically important systems are not found in the nematode, such as the immune system. The small size of C. elegans causes a certain difficulty in obtaining large amounts of nematodes at late ages in order to be used for the assessment of LGG-1 (LC3, GABARAP and GATE-16 family-1) lipidation for example. However, challenging methods for the cultivation of large numbers of aged worms have been developed and both protein and mRNA levels are estimated as a function of age [151-153].

\subsection{Autophagy in Caenorhabditis elegans}

The use of animal models is essential for understanding the role of autophagy in development, cell death, and multiple pathologies throughout an entire lifespan. Various nematode models of autophagy-related human pathologies, such as neurodegeneration, metabolic disorders, immune and infectious diseases exist [154]. In C. elegans autophagy occurs in many cell types and plays an essential role in physiology and development, such as survival under nutrient deprivation, removal of protein substrates, degeneration of 6 touch receptor neurons caused by toxic ion-channel variants, dauer formation, prevention of bacterial infection and ageing [155-162]. Genetic studies utilizing the aggrephagy pathway during embryogenesis revealed essential autophagy genes [162,163]. High conservation of autophagy genes and respective molecular mechanisms between $C$. elegans, yeast and mammals paved the way for the use of the nematode to study autophagy under the context 
of development, ageing, and pathophysiology (Table 1). Approaches to monitor and study autophagy in C. elegans are constantly expanding [164-166].

Table 1. Evolutionarily conserved autophagy-related genes of Caenorhabditis elegans.

\begin{tabular}{|c|c|c|c|c|}
\hline & C. elegans & Mutant Allele & Homo Sapiens & Reference \\
\hline $\begin{array}{l}\text { Initiation/ } \\
\text { ULK1 complex }\end{array}$ & $\begin{array}{l}\text { unc-51 } \\
\text { epg-1 } \\
\text { epg-7 } \\
\text { epg-9 }\end{array}$ & $\begin{array}{c}\text { e369 } \\
\text { bp417 } \\
t m 2508 \\
\text { bp320 }\end{array}$ & $\begin{array}{c}\text { ULK1, ULK2 } \\
\text { ATG13 } \\
\text { RB1CC1 (FIP200) } \\
\text { ATG101 }\end{array}$ & $\begin{array}{c}108,155,157,167] \\
{[168]} \\
{[169]} \\
{[170]}\end{array}$ \\
\hline $\begin{array}{c}\text { Nucleation/ } \\
\text { PI3KC3 complex }\end{array}$ & $\begin{array}{l}\text { epg-8 } \\
\text { bec-1 } \\
\text { ops-15 } \\
\text { ops-34 }\end{array}$ & $\begin{array}{c}\text { bp251, ok2561 } \\
\text { ok691, ok700, bp613 } \\
\text { or1235, ok3132 } \\
h 741\end{array}$ & $\begin{array}{c}\text { ATG14 } \\
\text { BECN1 } \\
\text { PIK3R4 (VPS15) } \\
\text { PIK3C3 }\end{array}$ & $\begin{array}{c}{[171]} \\
{[155,172-176]} \\
{[177]} \\
{[178]}\end{array}$ \\
\hline $\begin{array}{l}\text { Phagophore formation/ } \\
\text { PI3P binding }\end{array}$ & $\begin{array}{c}\text { atg-2 } \\
\text { atg-9 } \\
\text { atg-18 }\end{array}$ & $\begin{array}{c}b p 576 \\
b p 564 \\
g k 378, b p 594\end{array}$ & $\begin{array}{c}\text { ATG2A, ATG2B } \\
\text { ATG9A, ATG9B } \\
\text { WIPI1, WIPI2 }\end{array}$ & $\begin{array}{c}{[179]} \\
{[179]} \\
{[162,176,180,181]}\end{array}$ \\
\hline $\begin{array}{l}\text { Phagophore formation/ } \\
\text { ATG12 conjugation } \\
\text { system }\end{array}$ & $\begin{array}{c}\text { atg-5 } \\
\text { atg-7* } \\
\text { atg-10 } \\
\operatorname{lgg}-3 \\
\text { atg-16.1 } \\
\text { atg-16.2 }\end{array}$ & $\begin{array}{c}b p 484 \\
b p 422, b p 290 \\
b p 421 \\
t m 1462 \\
g k 668615 \\
b p 636, o k 3224\end{array}$ & $\begin{array}{c}\text { ATG5 } \\
\text { ATG7 } \\
\text { ATG10 } \\
\text { ATG12 } \\
\text { ATG16L1 } \\
\text { ATG16L2 }\end{array}$ & $\begin{array}{c}{[182]} \\
{[155,174,176,179,183]} \\
{[183]} \\
{[183]} \\
{[182]} \\
{[176,182]}\end{array}$ \\
\hline & $e p g-6^{* *}$ & $b p 242$ & $\begin{array}{l}\text { WDR45B (WIPI3), } \\
\text { WDR45 (WIPI4) }\end{array}$ & [179] \\
\hline $\begin{array}{c}\text { Phagophore } \\
\text { elongation/ } \\
\text { LC3 coniugation }\end{array}$ & $\begin{array}{l}\text { atg-3 } \\
\operatorname{atg}-4.1 \\
\operatorname{atg}-4.2\end{array}$ & $\begin{array}{c}b p 412 \\
b p 501 \\
t m 3948\end{array}$ & $\begin{array}{c}\text { ATG3 } \\
\text { ATG4A, ATG4B } \\
\text { ATG4C, ATG4D } \\
\text { GABARAP. }\end{array}$ & $\begin{array}{l}{[183]} \\
{[184]} \\
{[184]}\end{array}$ \\
\hline system & $\operatorname{lgg}-1$ & bp500, tm3489 & $\begin{array}{l}\text { GABARAPL1, } \\
\text { GABARAPL2 }\end{array}$ & {$[155,162,185,186]$} \\
\hline & $\operatorname{lgg}-2$ & $\operatorname{tm} 5755$ & $M A P 1 L C 3 B$ & [185-187] \\
\hline $\begin{array}{l}\text { Autophagosome- } \\
\text { lysosome fusion }\end{array}$ & $\begin{array}{l}\operatorname{lmp}-1 \\
\text { snap-29 } \\
\text { syx-17 } \\
\text { ops-39 }\end{array}$ & $\begin{array}{c}n r 2045 \\
t m 2060 \\
- \\
t m 2253, o k 2442\end{array}$ & $\begin{array}{l}\text { LAMP1 } \\
\text { SNAP29 } \\
\text { STX17 } \\
\text { VPS39 }\end{array}$ & $\begin{array}{c}{[188,189]} \\
{[180,190]} \\
{[191]} \\
{[186]}\end{array}$ \\
\hline $\begin{array}{c}\text { Negative regulation } \\
\text { of autophagosome } \\
\text { assembly }\end{array}$ & $\begin{array}{l}\text { epg-2 } \\
\text { epg-3 } \\
\text { epg-4 } \\
\text { epg-5 }\end{array}$ & $\begin{array}{c}b p 287, b p 444 \\
b p 405 \\
b p 425 \\
b p 450, t m 3425\end{array}$ & $\begin{array}{c}- \\
V M P 1 \\
\text { EI24 } \\
\text { EPG5 }\end{array}$ & $\begin{array}{c}{[168]} \\
{[162,168]} \\
{[162,168]} \\
{[162]}\end{array}$ \\
\hline $\begin{array}{l}\text { Autophagy gene } \\
\text { regulation }\end{array}$ & $\begin{array}{l}\text { let-363 } \\
\text { vps-41 }\end{array}$ & $\begin{array}{l}h 98, h 111 \\
\text { ep } 402\end{array}$ & $\begin{array}{l}M T O R \\
V P S 41\end{array}$ & $\begin{array}{c}{[158,160,192,193]} \\
{[186]}\end{array}$ \\
\hline Autophagy receptors & $\begin{array}{l}\text { sepa-1 } \\
\text { sqst }-1\end{array}$ & $\begin{array}{c}b p 456 \\
o k 2892\end{array}$ & $\stackrel{-}{\text { SQSTM1 (p62) }}$ & $\begin{array}{l}{[168]} \\
{[169]}\end{array}$ \\
\hline Endosome transport & $\begin{array}{l}r a b-7 \\
r a b-10\end{array}$ & $\begin{array}{c}\text { ok511, } t \text { m3300 } \\
\text { ok1494 }\end{array}$ & $\begin{array}{l}R A B 7 A \\
R A B 10\end{array}$ & $\begin{array}{c}{[185,186,194-196]} \\
{[197,198]}\end{array}$ \\
\hline
\end{tabular}

Human gene and previous/alias (in parentheses) approved symbols according to HUGO Gene Nomenclature Committee (https: / www. genenames.org/ accessed on 20 March 2021). * Participates at LC3 conjugation system as well. ** Participates at phagophore elongation as well.

Emerging evidence implicate neuronal selective autophagy in the development of neurodegenerative diseases [199]. A relatively high degree of redundancy of SARs not only denote the importance of selective autophagy but also render the study of selective autophagy more complex and challenging. For example, p62/SQSTM1 (sequestosome 1), NBR1 (neighbor of BRCA1 gene 1 autophagy cargo receptor), TAX1BP1 (Tax1 binding protein 1), NDP52 (52-kDa nuclear dot protein), OPTN (optineurin), TOLLIP (toll interacting protein), ATG16L1, ALFY (autophagy-linked FYVE) and TRIM5 (tripartite motif containing 
5) serve as selective aggrephagy receptors; BNIP3 (BCL2 interacting protein 3), NIX (Nip3like protein X), FUNDC1 (FUN14 domain containing 1), BCL2L13 (BCL2 like 13), FKBP8 (FK506-binding protein 8), PHB2 (prohibitin 2), NIPSNAP1/2 (4-nitrophenylphosphatase domain and non-neuronal SNAP25-like proteins 1 and 2), NPD52, OPTN, AMBRA1 serve as selective mitophagy receptors and FAM134B (family with sequence similarity 134 member B), Sec62 (SEC62 homolog, preprotein translocation factor), RTN3 (reticulon 3), CCPG1 (cell cycle progression 1), ATL3 (atlastin GTPase 3) and TEX264 (testis expressed 264) serve as selective ER-phagy receptors (reviewed in [199]). Studies in lower organisms with less developed SAR (but also ATG8 family) repertoire such as C. elegans can serve as ideal abstract model in dissecting key features and roles of selective autophagy.

Inefficient or impaired autophagy has been linked to neurodegenerative disorders, such as Parkinson's, Alzheimer's and Huntington's disease. However, it has been reported that autophagy effect on neuronal integrity is developmental-stage dependent. While increased levels or intact autophagy in ageing cells and organisms render enhanced health span and longevity, in early developmental life can be harmful [200]. Such a model of antagonistic pleiotropy effect of autophagy during development and ageing can be easily studied utilizing C. elegans under standard laboratory conditions.

\subsection{Interplay between Autophagy and Ageing in Caenorhabditis elegans}

In C. elegans, it is feasible to monitor and study age-dependent accumulation of immature autophagosomes and decreased autophagic degradation across all tissues in vivo over the organismal lifetime [201]. Long-lived mutants, such as daf-2 [impaired insulin/IGF1 (insulin-like growth factor-1) receptor signaling], let-363/TOR(RNAi) (impaired TOR signaling), eat-2 (diet restriction), clk-1 (mitochondrial respiration deficiency) and $g l p-1$ (germline-deficiency), require autophagy and exhibit increased puncta levels of the GFP (green fluorescent protein) tagged ortholog of human GABARAPL1, LGG-1, as well as increased expression of several autophagy genes [156,180,202-204]. Extended longevity of daf-2 mutant worms is bec-1-, atg-7-, atg-12- and lgg-1-dependent [155]. daf-2 mutants also require the transcription factor DAF-16/FOXO (abnormal dauer formation-16/forkhead box $\mathrm{O}$ ) for enhanced longevity, which promotes the upregulation of atg genes in worms, flies and mammals [122,205,206]. During age-related autophagy dysregulation, inhibition of early steps of autophagosome nucleation via inactivation of pha-4 (defective pharynx development-4) or bec-1 leads to improved muscle integrity, neuroprotection, healthspan and lifespan [207].

\section{Neuronal Autophagy in Ageing: Insights from Caenorhabditis elegans \\ 3.1. Autophagy Induction}

In eukaryotes, $\mathrm{AMPK}$ is the nutrient and energy sensor that functions to maintain cellular energy homeostasis [208,209]. AMPK regulates autophagy by at least two main modes of action. Firstly, via direct phosphorylation of mammalian TOR-binding partner raptor, mediating mTOR pathway inhibition [210]. Secondly, via direct phosphorylation of ULK1 [211,212]. Apart from the above roles in autophagy regulation, AMPK plays a role in ageing as well [213]. In C. elegans, increased gene dosage or activation of AAK-2 (AMP-activate kinase-2) catalytic $\alpha$ subunit, extends lifespan [214-218]. In the case of diet restriction-induced longevity, a single pair of sensory neurons in the head (ASIs) act cell non-autonomously to signal in peripheral non-neuronal body tissues to increase metabolic activity [219].

Ectopic expression of ANMT-1/NNMT (amine N-methyltransferase-1/nicotinamide $N$-methyltransferase) maintains neuronal function in old wild type and various disease model worms, affecting longevity as well [220]. When NNMT is ectopically expressed in human and rat neuronal cells exerts neuroprotective effects through ephrin B2 and Akt signaling, regulating energy homeostasis. ANMT-1 competes with LCMT-1 (leucine methyltransferase homolog-1) for methyl groups from SAM (S-adenosyl-methionine) [221,222]. Under physiological cellular SAM levels, LCMT-1 activity leads to autophagy inhibition 
through LET-92/PP2CA (lethal-92/protein phosphatase 2 catalytic subunit alpha) and NPRL-2/NPRL2 (nitrogen permease regulator like homolog-2/NPR2-like, GATOR1 complex subunit). When ectopically expressed, ANMT-1 methylates NAM (nicotinamide) to MNA ( $N$-methylnicotinamide). The reaction is irreversible causing SAM and therefore methyl groups scarcity [223]. LCMT-1 is unable to elicit its physiological inhibitory activity. Therefore, autophagy is activated and neuronal function is ameliorated in ageing worms. On the other hand, in younger worms, ANMT-1 activity caused abnormal behavior, disturbing neuronal homeostasis and dopamine signaling, possibly due to excessive autophagy. The above example shows that ectopic genetic interventions obey to the universal antagonistic pleiotropic theory as well. Age-correlated studies in model organisms along with biochemical, genetic and cellular observations allows in depth understanding of naturally fine-tuned biological processes in organismal lifespan dimension.

\subsection{PI3K Complex and PI3P}

Autophagic activity decreases with animal ageing in many species including C. elegans [201]. Age-related decline of autophagy takes place in several tissues such as intestine, body-wall muscle, pharynx, and neurons of wild type animals. Autophagy is considered as a convergent process of several longevity interventions including calorie restriction, insulin/IGF-1 or TOR signaling inhibition, germline removal and reduced mitochondrial respiration $[155,156,158,160,203]$. Rubicon (run domain Beclin-1 interacting and cysteinerich containing protein), an autophagy related protein that binds to the PI3K complex and negatively regulates autophagy, inhibits both autophagosome-lysosome fusion and endocytic trafficking [224,225]. Age-dependent increase of Rubicon expression in worms, flies and mice, impairs autophagy over time, causing animal healthspan decline [226]. Knockdown of Rubicon specifically in neurons has the greatest effect on lifespan extension comparing to hypodermal or intestinal knockdown. Furthermore, Rubicon knockdown ameliorates several age-associated phenotypes, such as polyglutamine aggregation in body wall muscles, decline in locomotion and oxidative stress resistance in an autophagydependent manner, rendering increased expression of Rubicon an autophagy-related signature of ageing.

DAF-2/IGF-1 (abnormal dauer formation-2/insulin-like growth factor-1) and its major transcription factor target DAF-16/FOXO regulate longevity in C. elegans [227-229]. ATG-18/WIPI2 sufficiently mediates the DAF-2 longevity signal. It acts specifically in chemosensory neurons and intestinal cells of $C$. elegans to maintain lifespan and respond to dietary restriction, in a cell non-autonomous manner, through the release of neurotransmitters and neuropeptides [181].

\subsection{ATG8}

During C. elegans development LGG-1 and LGG-2, share similar expression and localization pattern. However, GFP::LGG-2 is more abundant in some head and tail neurons and the neuron cell bodies of the ventral nerve cord where might play a particular role [185]. As reported for LC3 in mammalian cells, autophagic flux can be measured in whole animals or specifically in a particular tissue of C. elegans utilizing LGG-1 tandemly tagged with two fluorescent proteins at the $\mathrm{N}^{\prime}$ terminus (Cerulean-Venus) $[230,231]$. Release of a monomeric fluorescent protein upon arrival at the lysosome shows increased autophagic flux primarily in intestine, hypodermis and muscle cells and to a smaller extend in pharynx and neurons on day 5 animals compared to first-stage larvae.

Monitoring autophagic vesicle formation from day 1 to day 10 of adulthood of $C$. elegans using transgenic animals expressing either $g f p:: \operatorname{lgg}-1$ or mcherry::gfp:lgg-1 reporters indicate that the steady-state number of autophagosomes increases with age in intestine, muscle, pharynx and neurons, albeit with different trajectories [201]. Interestingly, the steady-state number of autolysosomes increases until day 3 to 5 but then somehow stagnate in intestine, muscle and pharynx whereas the number of autolysosomes decreases over time in neurons. The increased number of autophagosomes, which is not accompanied by 
increased number of autolysosomes, might reflect an age-dependent decline in autophagic activity in those major tissues. The above decline occurs at a step after autophagosome formation. In the same study, it is suggested that neuronal autophagic activity of the longlived daf-2 insulin/IGF-1 receptor mutant or the germline-less $g l p-1$ Notch receptor mutant is higher in early adulthood compared to wild type, whereas age-related impairment of neuronal autophagic activity takes place over mid-life similarly to wild type worms.

Functional neuronal autophagy is critical for the maintenance of normal axonal homeostasis and prevention of axonal degeneration under physiological and stress conditions [232-235]. Axonal damage responses include calcium influx, membrane sealing, activation of injury signaling, changes in transcription and autophagy activation [236-239]. Specifically, autophagy stabilizes microtubules, promotes axon regeneration and improves locomotor functional recovery in mice after spinal cord injury [240]. In addition, axon injury upregulates the autophagy genes Ambra, Atg5, Beclin 1 and LC3 in the central and peripheral nervous system [240,241]. In C. elegans, single neuron axotomy is feasible using a variety of lasers [242-245]. Tandem fluorescent-tagged LGG-1 monitoring during axon regeneration reveals increased number of autophagic vesicles [246]. The capacity of animals for axon regeneration and autophagy activation after axonal injury undergo an age-dependent decline. Autophagy-activating agents fail to enhance axon regrowth in young PLM neurons but interestingly succeed to partially rescue these defects in old neurons. Furthermore, autophagy activation after injury depends on DLK-1/MAP3K12 (dual-leucine zipper kinase-1/mitogen-activated protein kinase kinase kinase 12) and LIN-12/NOTCH4 ( $\mathrm{Ca}^{2+}$ signaling. Abnormal cell lineage-12/notch 4 receptor), identified previously as an inhibitor of axon regeneration, colocalizes with autophagic vesicles in PLM neurons suggesting that LIN-12 might be a target of autophagy during axon regeneration [246-248]. This example suggests that pharmacological activation of autophagy in aged animals can specifically enhance neuronal axon regeneration boosting the age-attenuated regrowth capacity.

Young adult animals expressing amyloid- $\beta_{3-42}$ or polyglutamine $\left(Q_{40}\right)$ in neuronal cells show increased levels of LGG-1 and moderate increased levels of SQST-1 (sequestosome 1)/p62 via immunodetection, indicating impairment of autophagy [249]. Whether such an increase represents transcriptional induction of LGG-1 and SQST-1 was not examined.

$\beta$-amyrin, a pentacyclic triterpene found in many medicinal plants, shows a protective effect on dopaminergic neurons by reducing dendrite blebbing or rounding induced by 6OHDA (6-hydroxydopamine) [250]. In addition, $\beta$-amyrin reduces $\alpha$-synuclein aggregation in muscle cells, upregulates $\operatorname{lgg}-1$ mRNA levels and increases the number of GFP::LGG-1 puncta in seam cells.

\subsection{SQST-1/p62}

In C. elegans, SQST-1 is required for autophagosome formation in neurons, rather than for increasing the rate of (or facilitating the) autophagosomal turnover [251]. sqst-1 mutant animals display a tissue-specific block in autophagy in nerve-ring neurons. Unlike core autophagy genes, sqst- 1 is not implicated in other conserved longevity paradigms, including daf-2/insulin/IGF-1 receptor and germline-less $g l p-1$ mutants or animals with reduced levels of mTOR and reduced levels of components of the mitochondrial electron transport chain (let-363 and cyc-1 RNAi, respectively) [139]. However, sqst-1 is required under specific, potentially proteotoxic conditions, such as a hormetic heat shock. In contrast to wild type animals in which a hormetic heat shock reduces aggregation, sqst-1 mutant animals expressing neuronal polyglutamine show an increased aggregate load in neurons following a hormetic heat shock [251,252]. Both hormetic heat shock- and HSF-1 (heat shock factor-1)-mediated survival require the autophagy genes unc-51, bec-1 and $\operatorname{lgg}-1$ as well. SQST-1 overexpression is sufficient to induce neuronal (and intestinal) autophagy and results in lifespan extension in an autophagy-dependent manner. Interaction of SQST1 with ubiquitinated proteins is required for SQST-1 overexpression lifespan extension. Overexpression of SQST-1 results in lifespan extension and improved proteostasis in 
C. elegans strains with protein-folding defects or under proteotoxic conditions as well. Specifically, while the number of neuronal polyglutamine aggregates is unchanged, the mobility of both the aggregated and the diffuse polyglutamine proteins is increased upon overexpression of SQST-1.

\subsection{Autophagosome Formation}

A systematic analyses utilizing genetic ablation of ATG proteins and markers for synaptic vesicle clustering, cytoskeleton organization and active zone position in C. elegans, revealed the role of 18 distinct autophagy genes in neuronal development [253]. Specifically, ATG proteins covering all the stages from autophagosome biogenesis until maturation are required for clustering of the synaptic vesicle proteins RAB-3 and SNB-1 (synaptobrevin-1) in AIY interneurons during development. In contrast, the selective autophagy genes atg-11, the nematode specific epg-2 and sqst-1 do not show AIY presynaptic defects. Retention of the respective rescuing array for either atg-9, $\operatorname{lgg}-1$, or atg-2 mutants in AIY neurons results in rescue of the AIY presynaptic defects. Retention of the same rescuing array in other neurons (including postsynaptic partner RIA), but not in AIY neurons, does not result in rescue of the AIY presynaptic defects. Therefore, autophagy acts in a cell-autonomous manner in AIY neurons to promote synaptic vesicle clustering. Additionally, defects in autophagy affect different elements of presynaptic assembly, namely the localization of F-actin and the active zone protein SYD-1 (synapse defective protein-1) to presynaptic sites. However, autophagy is not required for the development of the glia that specifies the synaptic positions in AIY. Autophagosomes are present in cell bodies and near presynaptic sites of developing AIY and nociceptive sensory PVD neurons in C. elegans embryos when axon outgrowth and synaptogenesis occur. Endogenous ATG-9 in both adults and 3-fold embryos is present pan-neuronally. Moreover, ATG-9 is enriched in presynaptic regions and colocalizes with RAB-3 in AIY neurons in an UNC-104/KIF1A (uncoordinated-104/kinesin family member 1A)-dependent manner. Similarly, punctate ATG-9 colocalizes with RAB-3 in nociceptive sensory PVD neurons. Autophagy deficiency in distinct steps of the process leads to significantly longer outgrowth of the nociceptive sensory PVD axon in L3, L4 and adult worms.

Presynaptic neurons can regulate synaptic clustering of postsynaptic muscle cell receptors selectively through autophagy [108]. Loss of GABA- and acetylcholine-dependent innervation causes increased autophagy in muscle cells and autophagosome engagement of $\mathrm{GABA}_{\mathrm{A}}$ receptors after endocytosis from cell membrane. On the contrary, under the same condition, acetylcholine receptors do not show any autophagosome localization in the same cells, indicating that autophagy targets $\mathrm{GABA}_{\mathrm{A}}$ receptors selectively. The above mechanism provides control of $\mathrm{GABA}_{\mathrm{A}}$ inhibitory synapse activity while leaves acetylcholine excitatory synapse activity unaffected through autophagy.

The atypical E3 ubiquitin ligase, RPM-1/MYCBP2 (regulator of presynaptic morphology$1 /$ MYC binding protein 2) restricts UNC-51 activity and furthermore autophagosome formation specifically at the axon termination sites affecting initiation of autophagy in mechanosensory neurons [254]. Worms lacking rpm-1 show elevated UNC-51 levels in axon termination sites, which causes excessive autophagy initiation and autophagosome formation. The above leads to abnormal axon termination, synapse maintenance and behavioral habituation.

Among several toxic protein aggregates, autophagy plays a critical role in removal of tau [255-258]. Axon injury-induced autophagy and furthermore axon regeneration capacity are reduced in transgenic $C$. elegans expressing the highly amyloidogenic tau species F3 $\Delta$ K280, but not the anti-aggregant tau (with I277P and I308P introduction) $[259,260]$. In addition, pro-aggregant tau impairs autophagic vesicle trafficking across neuron axons. Autophagy inducers reduce the accumulation of misfolded and aggregated proteins, attenuating the spreading of tau and neuronal damage [259,261-267]. Either rapamycin treatment or axon-injury is sufficient to enhance the number and trafficking of autophagic vesicles in young wild type PLM neurons. In contrast, neither rapamycin nor axon injury 
after axotomy was able to induce the formation or trafficking of autophagic vesicles in young PLM neurons of the tauopathy model [260]. However, it would be of particular interest to compare autophagy responses of the above experimental set during ageing. Interestingly, loss of the C. elegans homolog of tau, PTL-1 (protein with tau-like repeats-1), leads to increased basal level of autolysosomes and impaired autophagy activation after injury. Therefore, tau depletion as well as aggregation modulate autophagy responses in neurons after injury. It is not clear whether autophagy-lysosome system impairment is a contributor or a consequence of tauopathies [268,269].

Rho family small GTPases and furthermore actin cytoskeleton regulate neuronal axonogenesis and morphogenesis [270]. In C. elegans the small GTPase CED-10/RAC1 (cell death abnormality-10/Rac family small GTPase 1) has been associated with impaired autophagy and dopaminergic neuron death through $\alpha$-synuclein accumulation [271].

Infections by pathogenic microbes are suspected to trigger functional neuronal ageing through increased expression of immune molecules [272-274]. Some AMPs (antimicrobial peptides) were suggested to have non-antimicrobial functions in the neurons $[275,276]$. Age-associated expression of NLP-29 (neuropeptide-like protein-29), an AMP expressed in hypodermis, causes dendrite degeneration via the orphan GPCR (G protein-coupled receptor) NPR-12 (neuropeptide receptor-12) and autophagy induction in PVD neurons of C. elegans [277]. The same NLP-29/NPR-12 pathway causes dendrite degeneration through autophagy in rat cortical neurons suggesting evolutionally conservation.

Polyamine supplementation or inhibition of polyamine catabolism (which leads to increased intracellular polyamine levels) extends lifespan and rescues worms from age-associated neurodegeneration derived from manganese toxicity in an autophagydependent manner $[278,279]$. The above neuroprotective effect of polyamines is proposed to be exerted through translational regulation.

\subsection{TFEB}

TFEB (transcription factor EB) controls the expression of genes involved both in the lysosomal biogenesis and function and in major steps of autophagy, including autophagosome formation and autophagosome-lysosome fusion [280]. TFEB dysregulation is associated with neurodegenerative diseases and TFEB overexpression promotes neuroprotection [281-284]. Heterozygous loss-of-function mutations of the neurodegenerative disease protein PGRN (progranulin) result in TDP-43 (TAR DNA binding protein-43) inclusions and cause frontotemporal lobar degeneration [285-287]. Loss of both gene alleles leads to the lysosomal storage disease, neuronal ceroid lipofuscinosis [288]. In C. elegans, granulins, the cleavage products of progranulin, accumulate in the endolysosomal compartment and impair lysosomal function during ageing [289]. Furthermore, granulin expression may result in neuronal dysfunction and granulin-expressing animals show impaired short-term associative learning. Disrupted protein homeostasis causes nuclear translocation of HLH-30 (helix-loop-helix-30)/TFEB, in order to induce expression of genes involved in lysosomal function and autophagy, as well as progranulin.

\subsection{Mitophagy}

Mitophagy, the selective degradation of damaged or superfluous mitochondria by autophagy, is implicated in neurodegeneration and ageing [290-292]. Age-related mitochondrial dysfunction or damage play a prominent role in Alzheimer's disease [293-295]. Expectedly, mitophagy is impaired in Alzheimer's disease C. elegans models [296]. In both amyloid- $\beta$ and tau model nematodes, mitophagy enhancement reverses memory impairment through PINK-1 (PTEN-induced kinase-1)-, PDR-1 (Parkinson's disease related 1)/-, or DCT-1 (DAF-16/FOXO controlled, germline tumor affecting-1)-dependent pathways. Patients carrying different FTD (frontotemporal dementia) tau mutations show diverse pathological features [297-299]. The toxicity of different tau mutations on neuronal mitophagy in C. elegans varies as well. The FTD P301L mutant tau is more detrimental than wild type tau. Animals expressing the V337M mutant tau (another mutation found in fa- 
milial cases of FTD) display an intermediate mitophagy impairment in neurons in response to $\mathrm{NaN}_{3}$ [300].

Overexpression of UCP-4/SLC25A27 (uncoupling protein-4/solute carrier family 25 member 27) ameliorates neuronal integrity during ageing in C. elegans [301]. Animals overexpressing UCP-4 in mechanosensory touch receptor neurons show decreased mitochondrial membrane potential as well. Mitophagy-deficient animals overexpressing UCP-4 fail to attenuate age-dependent neuronal defects. The above results, derived from a protein overexpression, resemble the effects reported for the activity of mitochondrial uncoupling agents and mitophagy inducers such as CCCP (carbonyl cyanide m-chlorophenyl hydrazone) and DNP (2,4-dinitrophenol).

\subsection{Aggrephagy}

Autophagy genes are employed in the degradation of protein aggregates. Distinct autophagy mutants exhibit different patterns of accumulation of SQST-1 aggregates in different tissues and developmental stages of $C$. elegans [302]. ATG genes and the metazoanspecific epg-3, epg-4 and epg-5 genes, are required for degradation of SQST-1 in all tissues in embryos. Loss of function of core autophagy genes causes differences in SQST-1 accumulation at the larval and adult stages. The $\operatorname{lgg}-1$ mutant shows the strongest defect in SQST-1 clearance. epg-3 and epg-4 mutants cause weaker defect in SQST-1 degradation at larval and adult stages. epg-3 is essential for SQST-1 removal in the hypodermal cells, while mild defect is monitored in the body wall muscle cells, neurons and intestine. epg-4 mutants exhibit weak defects in all tissues. epg-5 mutants show a weak autophagy defect in hypodermal cells at the embryonic stage. Finally, loss of function of calpain-2 (clp-2) causes accumulation of SQST-1 aggregates in hypodermis and neurons at larval and adult stages. In contrast, degradation of SQST-1 in body wall muscle and intestine is normal.

Posttranslational modification of the human mutant Huntingtin by acetylation at lysine residue 444 shows improved clearance of the mutant protein in chemosensory neurons of $C$. elegans and may prevent cellular dysfunction and neurodegeneration in Huntington's disease [303]. While mutant Huntingtin expression results in degeneration of chemosensory neurons, co-expression of CBP (CREB-binding protein) results in neuroprotection. Such a neuroprotection activity is abolished when CBP is co-expressed along with the acetylation-resistant mutant Huntingtin, suggesting that CBP-mediated neuroprotection in C. elegans requires intact lysine 444 .

\section{Concluding Remarks}

Studies in long-lived models of $C$. elegans provide evidence for the important role of multiple ATG genes, establishing a link between autophagy and ageing (Table 2). It is becoming obvious that differential regulation of autophagy utilizes multiple ways to increase lifespan in a cell-autonomous or cell-non-autonomous manner. Autophagy declines in a tissue- and type-specific manner upon normal ageing. One possible explanation for the above observation could involve tissue-specific increased activity of the nutrient sensor mTOR upon ageing, which negatively regulates autophagy [304,305]. In addition, ageing negatively affects several steps of the autophagic process and lysosome activity. These include autophagosome transport in neurons, autophagosome accumulation in C. elegans and mice livers, lysosomal acidification in yeast and lysosomal protease activity in $C$. elegans [117,201,207,306-308]. Neuronal cells have developed unique and unconventional mechanisms to regulate autophagy. Spatiotemporal regulation of autophagy is implicated in neurotransmitter release, neuronal plasticity and behavioral outputs. A plethora of research avenues is open for future investigation. The emerging interest in the selectivity of autophagic cargo in neurons dictates the need for development of novel reporters for monitoring selective autophagy in vivo and in vitro. Since, it is known that neuronal activity and plasticity modulate the proteasomal system, correlative monitoring of autophagy and proteasome activity would gain insight in neuronal proteostasis regulation upon ageing [309-311]. Non-canonical roles of autophagy with possible link to ageing 
deserve further elucidation, such as the molecular and functional distinction between secretory and degradative autophagosomes in neurons. Organelle isolation and purification such as autophagosomes from different neuronal populations and compartments would shed light into age-dependent alterations in canonical and non-canonical functions of autophagy. Finally, autophagy may serve as a molecular and vesicular platform for pharmacological and genetic interventions to target specific substrates in a cellular/tissueand temporal-specific manner.

Table 2. Regulation of ageing by neuronal autophagy in Caenorhabditis elegans.

\begin{tabular}{|c|c|c|c|c|}
\hline Effector & Intervention & Mechanism & Effect & Reference \\
\hline AAK-2 & $\begin{array}{c}\text { Increased gene dosage } \\
\text { or activation }\end{array}$ & Autophagy initiation & Lifespan extension & [214-216,218,219] \\
\hline ANMT-1 & Neuronal expression & Autophagy initiation & $\begin{array}{l}\text { Lifespan regulation } \\
\text { in aged worms }\end{array}$ & [220] \\
\hline Rubicon & Neuronal knockdown & $\begin{array}{l}\text { Autophagosome- } \\
\text { lysosome fusion/ } \\
\text { endocytic trafficking }\end{array}$ & Lifespan extension & [226] \\
\hline ATG-18 & Mutant & $\begin{array}{l}\text { Neuronal and } \\
\text { intestinal } \\
\text { autophagosome } \\
\text { formation }\end{array}$ & $\begin{array}{l}\text { Dietary restriction- } \\
\text { and IGF-mediated } \\
\text { longevity }\end{array}$ & [181] \\
\hline DLK-1, LIN-12 & Axon injury & $\begin{array}{c}\text { Neuronal autophagic } \\
\text { degradation }\end{array}$ & $\begin{array}{l}\text { Enhanced neuronal } \\
\text { axon regeneration } \\
\text { upon autophagy } \\
\text { induction in aged }\end{array}$ & [246-248] \\
\hline$\beta$-amyrin & Administration & Autophagy induction & Neuroprotection & [250] \\
\hline SQST-1 & $\begin{array}{c}\text { Neuronal } \\
\text { overexpression }\end{array}$ & $\begin{array}{l}\text { Autophagosome } \\
\text { formation }\end{array}$ & Lifespan extension & [251] \\
\hline $\begin{array}{c}\text { ATG-9, LGG-1, } \\
\text { ATG-2 }\end{array}$ & Rescue in AIY neurons & $\begin{array}{l}\text { Synaptic vesicle } \\
\text { clustering }\end{array}$ & $\begin{array}{c}\text { Rescue of AIY } \\
\text { presynaptic defects }\end{array}$ & [253] \\
\hline 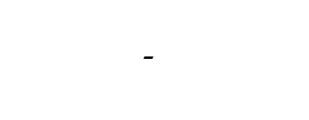 & Muscle innervation loss & $\begin{array}{l}\text { Autophagosome } \\
\text { engagement of } \\
\text { GABA }_{\mathrm{A}} \mathrm{Rs}\end{array}$ & $\begin{array}{c}\text { Postsynaptic } \\
\text { clustering regulation }\end{array}$ & [108] \\
\hline RPM-1 & Mutant & $\begin{array}{c}\text { Excessive } \\
\text { autophagosome } \\
\text { formation }\end{array}$ & $\begin{array}{l}\text { Abnormal axon } \\
\text { termination }\end{array}$ & [254] \\
\hline- & Axon injury & $\begin{array}{l}\text { Impaired autophagy } \\
\text { in tauopathy model }\end{array}$ & $\begin{array}{l}\text { Impaired axon } \\
\text { regeneration }\end{array}$ & [260] \\
\hline CED-10 & Mutant & Impaired autophagy & $\begin{array}{l}\alpha \text {-synuclein neuronal } \\
\text { inclusions }\end{array}$ & [271] \\
\hline NLP-29 & $\begin{array}{l}\text { Age-associated } \\
\text { expression }\end{array}$ & $\begin{array}{l}\text { Neuronal autophagy } \\
\text { induction } \\
\text { Transcriptional }\end{array}$ & $\begin{array}{c}\text { Dendrite } \\
\text { degeneration }\end{array}$ & [277] \\
\hline Spermine & Administration & $\begin{array}{l}\text { Iranscriptional } \\
\text { regulation of } \\
\text { autophagy }\end{array}$ & Neuroprotection & [279] \\
\hline Granulin & Endogenous expression & $\begin{array}{l}\text { HLH-30 nuclear } \\
\text { translocation }\end{array}$ & $\begin{array}{l}\text { Impaired short-term } \\
\text { associative learning }\end{array}$ & [289] \\
\hline $\begin{array}{l}\mathrm{NAD}^{+} \text {, urolithin } \mathrm{A}, \\
\text { actinonin }\end{array}$ & Administration & $\begin{array}{l}\text { Mitophagy } \\
\text { enhancement }\end{array}$ & $\begin{array}{l}\text { Inhibited amyloid- } \bar{\beta}- \\
\text { and tau-mediated } \\
\text { cognitive deficits }\end{array}$ & [296] \\
\hline Tau & Pan-neuronal expression & $\begin{array}{l}\text { Inhibition of } \\
\text { mitophagy }\end{array}$ & $\begin{array}{c}\text { Inhibited degradation } \\
\text { of damaged } \\
\text { mitochondria }\end{array}$ & [300] \\
\hline $\mathrm{UCP}-4$ & $\begin{array}{c}\text { Neuronal } \\
\text { overexpression }\end{array}$ & $\begin{array}{l}\text { Mitophagy } \\
\text { stimulation }\end{array}$ & $\begin{array}{c}\text { Attenuated } \\
\text { age-dependent } \\
\text { neurodegeneration } \\
\text { Tissue- and }\end{array}$ & [301] \\
\hline ATGs, EPGs, CLP-2 & Mutants & $\begin{array}{l}\text { Inhibition of } \\
\text { aggrephagy }\end{array}$ & $\begin{array}{c}\text { stage-specific } \\
\text { clearance of SQST-1 } \\
\text { aggregates }\end{array}$ & [302] \\
\hline CBP & $\begin{array}{c}\text { Neuronal } \\
\text { overexpression }\end{array}$ & $\begin{array}{c}\text { Autophagic clearance } \\
\text { of huntingtin * }\end{array}$ & Neuroprotection & [303] \\
\hline
\end{tabular}


Author Contributions: G.K. has prepared the original draft of the manuscript. G.K. and N.T. have revised and edited the manuscript. All authors have read and agreed to the published version of the manuscript.

Funding: This work was funded by grants from the European Research Council (ERC-GA695190MANNA) and the General Secretariat for Research and Innovation of the Greek Ministry of Development and Investments.

Informed Consent Statement: Informed consent was obtained from all subjects involved in the study.

Data Availability Statement: No new data were created or analyzed in this study. Data sharing is not applicable to this article.

Acknowledgments: We gratefully acknowledge the contributions of numerous investigators that we could not include in this review, owing to space limitations.

Conflicts of Interest: The authors declare no conflict of interest.

\section{References}

1. Kroemer, G.; Marino, G.; Levine, B. Autophagy and the integrated stress response. Mol. Cell 2010, 40, 280-293. [CrossRef] [PubMed]

2. Yang, Z.; Klionsky, D.J. Eaten alive: A history of macroautophagy. Nat. Cell Biol. 2010, 12, 814-822. [CrossRef]

3. Mizushima, N.; Komatsu, M. Autophagy: Renovation of cells and tissues. Cell 2011, 147, 728-741. [CrossRef] [PubMed]

4. Schuck, S. Microautophagy—Distinct molecular mechanisms handle cargoes of many sizes. J. Cell Sci. 2020, 133. [CrossRef] [PubMed]

5. Kaushik, S.; Cuervo, A.M. The coming of age of chaperone-mediated autophagy. Nat. Rev. Mol. Cell Biol. 2018, 19, 365-381. [CrossRef] [PubMed]

6. Xie, Z.; Klionsky, D.J. Autophagosome formation: Core machinery and adaptations. Nat. Cell Biol. 2007, 9, 1102-1109. [CrossRef]

7. Nakatogawa, H. Mechanisms governing autophagosome biogenesis. Nat. Rev. Mol. Cell Biol. 2020, 21, 439-458. [CrossRef]

8. Walker, S.A.; Ktistakis, N.T. Autophagosome Biogenesis Machinery. J. Mol. Biol. 2020, 432, 2449-2461. [CrossRef] [PubMed]

9. Takeshige, K.; Baba, M.; Tsuboi, S.; Noda, T.; Ohsumi, Y. Autophagy in yeast demonstrated with proteinase-deficient mutants and conditions for its induction. J. Cell Biol. 1992, 119, 301-311. [CrossRef] [PubMed]

10. Tsukada, M.; Ohsumi, Y. Isolation and characterization of autophagy-defective mutants of Saccharomyces cerevisiae. FEBS Lett. 1993, 333, 169-174. [CrossRef]

11. Thumm, M.; Egner, R.; Koch, B.; Schlumpberger, M.; Straub, M.; Veenhuis, M.; Wolf, D.H. Isolation of autophagocytosis mutants of Saccharomyces cerevisiae. FEBS Lett. 1994, 349, 275-280. [CrossRef]

12. Harding, T.M.; Morano, K.A.; Scott, S.V.; Klionsky, D.J. Isolation and characterization of yeast mutants in the cytoplasm to vacuole protein targeting pathway. J. Cell Biol. 1995, 131, 591-602. [CrossRef]

13. Ohsumi, Y. Historical landmarks of autophagy research. Cell Res. 2014, 24, 9-23. [CrossRef]

14. Maruyama, T.; Noda, N.N. Autophagy-regulating protease Atg4: Structure, function, regulation and inhibition. J. Antibiot. 2017. [CrossRef] [PubMed]

15. Johansen, T.; Lamark, T. Selective Autophagy: ATG8 Family Proteins, LIR Motifs and Cargo Receptors. J. Mol. Biol. 2020, 432, 80-103. [CrossRef]

16. Molino, D.; Zemirli, N.; Codogno, P.; Morel, E. The Journey of the Autophagosome through Mammalian Cell Organelles and Membranes. J. Mol. Biol. 2017, 429, 497-514. [CrossRef]

17. Ktistakis, N.T. ER platforms mediating autophagosome generation. Biochim. Biophys. Acta Mol. Cell Biol. Lipids 2020, $1865,158433$. [CrossRef]

18. Papinski, D.; Schuschnig, M.; Reiter, W.; Wilhelm, L.; Barnes, C.A.; Maiolica, A.; Hansmann, I.; Pfaffenwimmer, T.; Kijanska, M.; Stoffel, I.; et al. Early steps in autophagy depend on direct phosphorylation of Atg9 by the Atg1 kinase. Mol. Cell 2014, 53, 471-483. [CrossRef]

19. Maeda, S.; Yamamoto, H.; Kinch, L.N.; Garza, C.M.; Takahashi, S.; Otomo, C.; Grishin, N.V.; Forli, S.; Mizushima, N.; Otomo, T. Structure, lipid scrambling activity and role in autophagosome formation of ATG9A. Nat. Struct. Mol. Biol. 2020, 27, $1194-1201$. [CrossRef]

20. Matoba, K.; Kotani, T.; Tsutsumi, A.; Tsuji, T.; Mori, T.; Noshiro, D.; Sugita, Y.; Nomura, N.; Iwata, S.; Ohsumi, Y.; et al. Atg9 is a lipid scramblase that mediates autophagosomal membrane expansion. Nat. Struct. Mol. Biol. 2020, 27, 1185-1193. [CrossRef]

21. Sawa-Makarska, J.; Baumann, V.; Coudevylle, N.; von Bulow, S.; Nogellova, V.; Abert, C.; Schuschnig, M.; Graef, M.; Hummer, G.; Martens, S. Reconstitution of autophagosome nucleation defines Atg9 vesicles as seeds for membrane formation. Science 2020, 369. [CrossRef]

22. Guardia, C.M.; Tan, X.F.; Lian, T.; Rana, M.S.; Zhou, W.; Christenson, E.T.; Lowry, A.J.; Faraldo-Gomez, J.D.; Bonifacino, J.S.; Jiang, J.; et al. Structure of Human ATG9A, the Only Transmembrane Protein of the Core Autophagy Machinery. Cell Rep. 2020, 31, 107837. [CrossRef] [PubMed] 
23. Knorr, R.L.; Lipowsky, R.; Dimova, R. Autophagosome closure requires membrane scission. Autophagy 2015, 11, 2134-2137. [CrossRef]

24. Melia, T.J.; Lystad, A.H.; Simonsen, A. Autophagosome biogenesis: From membrane growth to closure. J. Cell Biol. 2020, 219. [CrossRef]

25. Reggiori, F.; Ungermann, C. Autophagosome Maturation and Fusion. J. Mol. Biol. 2017, 429, 486-496. [CrossRef]

26. Zhao, Y.G.; Zhang, H. Autophagosome maturation: An epic journey from the ER to lysosomes. J. Cell Biol. 2019, 218, 757-770. [CrossRef]

27. Dikic, I.; Elazar, Z. Mechanism and medical implications of mammalian autophagy. Nat. Rev. Mol. Cell Biol. 2018, 19, 349-364. [CrossRef]

28. Kawabata, T.; Yoshimori, T. Autophagosome biogenesis and human health. Cell Discov. 2020, 6, 33. [CrossRef] [PubMed]

29. Hara, T.; Nakamura, K.; Matsui, M.; Yamamoto, A.; Nakahara, Y.; Suzuki-Migishima, R.; Yokoyama, M.; Mishima, K.; Saito, I.; Okano, H.; et al. Suppression of basal autophagy in neural cells causes neurodegenerative disease in mice. Nature 2006, 441, 885-889. [CrossRef]

30. Komatsu, M.; Waguri, S.; Chiba, T.; Murata, S.; Iwata, J.; Tanida, I.; Ueno, T.; Koike, M.; Uchiyama, Y.; Kominami, E.; et al. Loss of autophagy in the central nervous system causes neurodegeneration in mice. Nature 2006, 441, 880-884. [CrossRef] [PubMed]

31. Kaushik, S.; Rodriguez-Navarro, J.A.; Arias, E.; Kiffin, R.; Sahu, S.; Schwartz, G.J.; Cuervo, A.M.; Singh, R. Autophagy in hypothalamic AgRP neurons regulates food intake and energy balance. Cell Metab. 2011, 14, 173-183. [CrossRef] [PubMed]

32. Aveleira, C.A.; Botelho, M.; Cavadas, C. NPY/neuropeptide Y enhances autophagy in the hypothalamus: A mechanism to delay aging? Autophagy 2015, 11, 1431-1433. [CrossRef] [PubMed]

33. Oh, T.S.; Cho, H.; Cho, J.H.; Yu, S.W.; Kim, E.K. Hypothalamic AMPK-induced autophagy increases food intake by regulating NPY and POMC expression. Autophagy 2016, 12, 2009-2025. [CrossRef]

34. Xiao, Y.; Deng, Y.; Yuan, F.; Xia, T.; Liu, H.; Li, Z.; Chen, S.; Liu, Z.; Ying, H.; Liu, Y.; et al. An ATF4-ATG5 signaling in hypothalamic POMC neurons regulates obesity. Autophagy 2017, 13, 1088-1089. [CrossRef]

35. Yan, J.; Porch, M.W.; Court-Vazquez, B.; Bennett, M.V.L.; Zukin, R.S. Activation of autophagy rescues synaptic and cognitive deficits in fragile X mice. Proc. Natl. Acad. Sci. USA 2018, 115, E9707-E9716. [CrossRef]

36. Fimia, G.M.; Stoykova, A.; Romagnoli, A.; Giunta, L.; Di Bartolomeo, S.; Nardacci, R.; Corazzari, M.; Fuoco, C.; Ucar, A.; Schwartz, P.; et al. Ambra1 regulates autophagy and development of the nervous system. Nature 2007, 447, 1121-1125. [CrossRef] [PubMed]

37. Cullup, T.; Kho, A.L.; Dionisi-Vici, C.; Brandmeier, B.; Smith, F.; Urry, Z.; Simpson, M.A.; Yau, S.; Bertini, E.; McClelland, V.; et al Recessive mutations in EPG5 cause Vici syndrome, a multisystem disorder with defective autophagy. Nat. Genet. 2013, $45,83-87$. [CrossRef]

38. Zhao, H.; Zhao, Y.G.; Wang, X.; Xu, L.; Miao, L.; Feng, D.; Chen, Q.; Kovacs, A.L.; Fan, D.; Zhang, H. Mice deficient in Epg5 exhibit selective neuronal vulnerability to degeneration. J. Cell Biol. 2013, 200, 731-741. [CrossRef] [PubMed]

39. Lv, X.; Jiang, H.; Li, B.; Liang, Q.; Wang, S.; Zhao, Q.; Jiao, J. The crucial role of Atg5 in cortical neurogenesis during early brain development. Sci. Rep. 2014, 4, 6010. [CrossRef]

40. Orosco, L.A.; Ross, A.P.; Cates, S.L.; Scott, S.E.; Wu, D.; Sohn, J.; Pleasure, D.; Pleasure, S.J.; Adamopoulos, I.E.; Zarbalis, K.S. Loss of Wdfy3 in mice alters cerebral cortical neurogenesis reflecting aspects of the autism pathology. Nat. Commun. 2014, 5, 4692. [CrossRef] [PubMed]

41. Cianfanelli, V.; Fuoco, C.; Lorente, M.; Salazar, M.; Quondamatteo, F.; Gherardini, P.F.; De Zio, D.; Nazio, F.; Antonioli, M.; D'Orazio, M.; et al. AMBRA1 links autophagy to cell proliferation and tumorigenesis by promoting c-Myc dephosphorylation and degradation. Nat. Cell Biol. 2015, 17, 706. [CrossRef]

42. Ebrahimi-Fakhari, D.; Saffari, A.; Wahlster, L.; Lu, J.; Byrne, S.; Hoffmann, G.F.; Jungbluth, H.; Sahin, M. Congenital disorders of autophagy: An emerging novel class of inborn errors of neuro-metabolism. Brain J. Neurol. 2016, 139, 317-337. [CrossRef]

43. Li, M.; Lu, G.; Hu, J.; Shen, X.; Ju, J.; Gao, Y.; Qu, L.; Xia, Y.; Chen, Y.; Bai, Y. EVA1A/TMEM166 Regulates Embryonic Neurogenesis by Autophagy. Stem Cell Rep. 2016, 6, 396-410. [CrossRef]

44. Miao, G.; Zhao, Y.G.; Zhao, H.; Ji, C.; Sun, H.; Chen, Y.; Zhang, H. Mice deficient in the Vici syndrome gene Epg5 exhibit features of retinitis pigmentosa. Autophagy 2016, 12, 2263-2270. [CrossRef]

45. Wang, Z.; Miao, G.; Xue, X.; Guo, X.; Yuan, C.; Zhang, G.; Chen, Y.; Feng, D.; Hu, J.; Zhang, H. The Vici Syndrome Protein EPG5 Is a Rab7 Effector that Determines the Fusion Specificity of Autophagosomes with Late Endosomes/Lysosomes. Mol. Cell 2016, 63, 781-795. [CrossRef] [PubMed]

46. Wu, X.; Fleming, A.; Ricketts, T.; Pavel, M.; Virgin, H.; Menzies, F.M.; Rubinsztein, D.C. Autophagy regulates Notch degradation and modulates stem cell development and neurogenesis. Nat. Commun. 2016, 7, 10533. [CrossRef]

47. Hori, I.; Otomo, T.; Nakashima, M.; Miya, F.; Negishi, Y.; Shiraishi, H.; Nonoda, Y.; Magara, S.; Tohyama, J.; Okamoto, N.; et al. Defects in autophagosome-lysosome fusion underlie Vici syndrome, a neurodevelopmental disorder with multisystem involvement. Sci. Rep. 2017, 7, 3552. [CrossRef] [PubMed]

48. Le Duc, D.; Giulivi, C.; Hiatt, S.M.; Napoli, E.; Panoutsopoulos, A.; Harlan De Crescenzo, A.; Kotzaeridou, U.; Syrbe, S.; Anagnostou, E.; Azage, M.; et al. Pathogenic WDFY3 variants cause neurodevelopmental disorders and opposing effects on brain size. Brain J. Neurol. 2019, 142, 2617-2630. [CrossRef] [PubMed]

49. Meneghetti, G.; Skobo, T.; Chrisam, M.; Facchinello, N.; Fontana, C.M.; Bellesso, S.; Sabatelli, P.; Raggi, F.; Cecconi, F.; Bonaldo, P.; et al. The epg5 knockout zebrafish line: A model to study Vici syndrome. Autophagy 2019, 15, 1438-1454. [CrossRef] 
50. Yeo, H.; Lyssiotis, C.A.; Zhang, Y.; Ying, H.; Asara, J.M.; Cantley, L.C.; Paik, J.H. FoxO3 coordinates metabolic pathways to maintain redox balance in neural stem cells. EMBO J. 2013, 32, 2589-2602. [CrossRef] [PubMed]

51. Gomez-Sanchez, J.A.; Carty, L.; Iruarrizaga-Lejarreta, M.; Palomo-Irigoyen, M.; Varela-Rey, M.; Griffith, M.; Hantke, J.; MaciasCamara, N.; Azkargorta, M.; Aurrekoetxea, I.; et al. Schwann cell autophagy, myelinophagy, initiates myelin clearance from injured nerves. J. Cell Biol. 2015, 210, 153-168. [CrossRef]

52. Jang, S.Y.; Shin, Y.K.; Park, S.Y.; Park, J.Y.; Lee, H.J.; Yoo, Y.H.; Kim, J.K.; Park, H.T. Autophagic myelin destruction by Schwann cells during Wallerian degeneration and segmental demyelination. Glia 2016, 64, 730-742. [CrossRef]

53. Xi, Y.; Dhaliwal, J.S.; Ceizar, M.; Vaculik, M.; Kumar, K.L.; Lagace, D.C. Knockout of Atg5 delays the maturation and reduces the survival of adult-generated neurons in the hippocampus. Cell Death Dis. 2016, 7, e2127. [CrossRef] [PubMed]

54. Casares-Crespo, L.; Calatayud-Baselga, I.; Garcia-Corzo, L.; Mira, H. On the Role of Basal Autophagy in Adult Neural Stem Cells and Neurogenesis. Front. Cell. Neurosci. 2018, 12, 339. [CrossRef] [PubMed]

55. Schaffner, I.; Minakaki, G.; Khan, M.A.; Balta, E.A.; Schlotzer-Schrehardt, U.; Schwarz, T.J.; Beckervordersandforth, R.; Winner, B.; Webb, A.E.; DePinho, R.A.; et al. FoxO Function Is Essential for Maintenance of Autophagic Flux and Neuronal Morphogenesis in Adult Neurogenesis. Neuron 2018, 99, 1188-1203.e6. [CrossRef] [PubMed]

56. Audesse, A.J.; Dhakal, S.; Hassell, L.A.; Gardell, Z.; Nemtsova, Y.; Webb, A.E. FOXO3 directly regulates an autophagy network to functionally regulate proteostasis in adult neural stem cells. PLoS Genet. 2019, 15, e1008097. [CrossRef] [PubMed]

57. Bankston, A.N.; Forston, M.D.; Howard, R.M.; Andres, K.R.; Smith, A.E.; Ohri, S.S.; Bates, M.L.; Bunge, M.B.; Whittemore, S.R. Autophagy is essential for oligodendrocyte differentiation, survival, and proper myelination. Glia 2019, 67, 1745-1759. [CrossRef]

58. Tang, G.; Gudsnuk, K.; Kuo, S.H.; Cotrina, M.L.; Rosoklija, G.; Sosunov, A.; Sonders, M.S.; Kanter, E.; Castagna, C.; Yamamoto, A.; et al. Loss of mTOR-dependent macroautophagy causes autistic-like synaptic pruning deficits. Neuron 2014, 83, 1131-1143. [CrossRef]

59. Kim, H.J.; Cho, M.H.; Shim, W.H.; Kim, J.K.; Jeon, E.Y.; Kim, D.H.; Yoon, S.Y. Deficient autophagy in microglia impairs synaptic pruning and causes social behavioral defects. Mol. Psychiatry 2017, 22, 1576-1584. [CrossRef]

60. Okerlund, N.D.; Schneider, K.; Leal-Ortiz, S.; Montenegro-Venegas, C.; Kim, S.A.; Garner, L.C.; Waites, C.L.; Gundelfinger, E.D.; Reimer, R.J.; Garner, C.C. Bassoon Controls Presynaptic Autophagy through Atg5. Neuron 2017, 93, 897-913.e7. [CrossRef]

61. Vanhauwaert, R.; Kuenen, S.; Masius, R.; Bademosi, A.; Manetsberger, J.; Schoovaerts, N.; Bounti, L.; Gontcharenko, S.; Swerts, J.; Vilain, S.; et al. The SAC1 domain in synaptojanin is required for autophagosome maturation at presynaptic terminals. $E M B O J$. 2017, 36, 1392-1411. [CrossRef]

62. Xiao, X.; Shang, X.; Zhai, B.; Zhang, H.; Zhang, T. Nicotine alleviates chronic stress-induced anxiety and depressive-like behavior and hippocampal neuropathology via regulating autophagy signaling. Neurochem. Int. 2018, 114, 58-70. [CrossRef]

63. Bhukel, A.; Beuschel, C.B.; Maglione, M.; Lehmann, M.; Juhasz, G.; Madeo, F.; Sigrist, S.J. Autophagy within the mushroom body protects from synapse aging in a non-cell autonomous manner. Nat. Commun. 2019, 10, 1318. [CrossRef]

64. Glatigny, M.; Moriceau, S.; Rivagorda, M.; Ramos-Brossier, M.; Nascimbeni, A.C.; Lante, F.; Shanley, M.R.; Boudarene, N.; Rousseaud, A.; Friedman, A.K.; et al. Autophagy Is Required for Memory Formation and Reverses Age-Related Memory Decline. Curr. Biol. CB 2019, 29, 435-448.e8. [CrossRef] [PubMed]

65. Zhu, J.W.; Zou, M.M.; Li, Y.F.; Chen, W.J.; Liu, J.C.; Chen, H.; Fang, L.P.; Zhang, Y.; Wang, Z.T.; Chen, J.B.; et al. Absence of TRIM32 Leads to Reduced GABAergic Interneuron Generation and Autism-like Behaviors in Mice via Suppressing mTOR Signaling. Cereb Cortex 2020, 30, 3240-3258. [CrossRef] [PubMed]

66. Kara, N.Z.; Toker, L.; Agam, G.; Anderson, G.W.; Belmaker, R.H.; Einat, H. Trehalose induced antidepressant-like effects and autophagy enhancement in mice. Psychopharmacology 2013, 229, 367-375. [CrossRef]

67. Merenlender-Wagner, A.; Malishkevich, A.; Shemer, Z.; Udawela, M.; Gibbons, A.; Scarr, E.; Dean, B.; Levine, J.; Agam, G.; Gozes, I. Autophagy has a key role in the pathophysiology of schizophrenia. Mol. Psychiatry 2015, 20, 126-132. [CrossRef] [PubMed]

68. Zhao, Z.; Zhang, L.; Guo, X.D.; Cao, L.L.; Xue, T.F.; Zhao, X.J.; Yang, D.D.; Yang, J.; Ji, J.; Huang, J.Y.; et al. Rosiglitazone Exerts an Anti-depressive Effect in Unpredictable Chronic Mild-Stress-Induced Depressive Mice by Maintaining Essential Neuron Autophagy and Inhibiting Excessive Astrocytic Apoptosis. Front. Mol. Neurosci. 2017, 10, 293. [CrossRef]

69. Al Eissa, M.M.; Fiorentino, A.; Sharp, S.I.; O’Brien, N.L.; Wolfe, K.; Giaroli, G.; Curtis, D.; Bass, N.J.; McQuillin, A. Exome sequence analysis and follow up genotyping implicates rare ULK1 variants to be involved in susceptibility to schizophrenia. Ann. Hum. Genet. 2018, 82, 88-92. [CrossRef]

70. Gulbins, A.; Schumacher, F.; Becker, K.A.; Wilker, B.; Soddemann, M.; Boldrin, F.; Muller, C.P.; Edwards, M.J.; Goodman, M.; Caldwell, C.C.; et al. Antidepressants act by inducing autophagy controlled by sphingomyelin-ceramide. Mol. Psychiatry 2018, 23, 2324-2346. [CrossRef]

71. Kara, N.Z.; Flaisher-Grinberg, S.; Anderson, G.W.; Agam, G.; Einat, H. Mood-stabilizing effects of rapamycin and its analog temsirolimus: Relevance to autophagy. Behav. Pharmacol. 2018, 29, 379-384. [CrossRef]

72. Sumitomo, A.; Yukitake, H.; Hirai, K.; Horike, K.; Ueta, K.; Chung, Y.; Warabi, E.; Yanagawa, T.; Kitaoka, S.; Furuyashiki, T.; et al. Ulk2 controls cortical excitatory-inhibitory balance via autophagic regulation of p62 and GABAA receptor trafficking in pyramidal neurons. Hum. Mol. Genet. 2018, 27, 3165-3176. [CrossRef] [PubMed]

73. Tan, X.; Du, X.; Jiang, Y.; Botchway, B.O.A.; Hu, Z.; Fang, M. Inhibition of Autophagy in Microglia Alters Depressive-Like Behavior via BDNF Pathway in Postpartum Depression. Front. Psychiatry 2018, 9, 434. [CrossRef] 
74. Geng, J.; Liu, J.; Yuan, X.; Liu, W.; Guo, W. Andrographolide triggers autophagy-mediated inflammation inhibition and attenuates chronic unpredictable mild stress (CUMS)-induced depressive-like behavior in mice. Toxicol. Appl. Pharmacol. $2019,379,114688$. [CrossRef]

75. He, S.; Zeng, D.; Xu, F.; Zhang, J.; Zhao, N.; Wang, Q.; Shi, J.; Lin, Z.; Yu, W.; Li, H. Baseline Serum Levels of Beclin-1, but Not Inflammatory Factors, May Predict Antidepressant Treatment Response in Chinese Han Patients With MDD: A Preliminary Study. Front. Psychiatry 2019, 10, 378. [CrossRef]

76. Shu, X.; Sun, Y.; Sun, X.; Zhou, Y.; Bian, Y.; Shu, Z.; Ding, J.; Lu, M.; Hu, G. The effect of fluoxetine on astrocyte autophagy flux and injured mitochondria clearance in a mouse model of depression. Cell Death Dis. 2019, 10, 577. [CrossRef]

77. Wang, Z.T.; Lu, M.H.; Zhang, Y.; Ji, W.L.; Lei, L.; Wang, W.; Fang, L.P.; Wang, L.W.; Yu, F.; Wang, J.; et al. Disrupted-inschizophrenia-1 protects synaptic plasticity in a transgenic mouse model of Alzheimer's disease as a mitophagy receptor. Aging Cell 2019, 18, e12860. [CrossRef] [PubMed]

78. Wang, Z.; Liu, S.; Pan, W.; Guo, Y.; Shen, Z. Bafilomycin A1 alleviates depressionlike symptoms in chronic unpredictable mild stress rats. Mol. Med. Rep. 2018, 18, 4587-4594. [CrossRef] [PubMed]

79. Hernandez, D.; Torres, C.A.; Setlik, W.; Cebrian, C.; Mosharov, E.V.; Tang, G.; Cheng, H.C.; Kholodilov, N.; Yarygina, O.; Burke, R.E.; et al. Regulation of presynaptic neurotransmission by macroautophagy. Neuron 2012, 74, 277-284. [CrossRef] [PubMed]

80. Binotti, B.; Pavlos, N.J.; Riedel, D.; Wenzel, D.; Vorbruggen, G.; Schalk, A.M.; Kuhnel, K.; Boyken, J.; Erck, C.; Martens, H.; et al. The GTPase Rab26 links synaptic vesicles to the autophagy pathway. eLife 2015, 4, e05597. [CrossRef] [PubMed]

81. George, A.A.; Hayden, S.; Stanton, G.R.; Brockerhoff, S.E. Arf6 and the 5'phosphatase of Synaptojanin 1 regulate autophagy in cone photoreceptors. Inside Cell 2016, 1, 117-133. [CrossRef]

82. Murdoch, J.D.; Rostosky, C.M.; Gowrisankaran, S.; Arora, A.S.; Soukup, S.F.; Vidal, R.; Capece, V.; Freytag, S.; Fischer, A.; Verstreken, P.; et al. Endophilin-A Deficiency Induces the Foxo3a-Fbxo32 Network in the Brain and Causes Dysregulation of Autophagy and the Ubiquitin-Proteasome System. Cell Rep. 2016, 17, 1071-1086. [CrossRef]

83. Soukup, S.F.; Kuenen, S.; Vanhauwaert, R.; Manetsberger, J.; Hernandez-Diaz, S.; Swerts, J.; Schoovaerts, N.; Vilain, S.; Gounko, N.V.; Vints, K.; et al. A LRRK2-Dependent EndophilinA Phosphoswitch Is Critical for Macroautophagy at Presynaptic Terminals. Neuron 2016, 92, 829-844. [CrossRef] [PubMed]

84. Soukup, S.F.; Verstreken, P. EndoA/Endophilin-A creates docking stations for autophagic proteins at synapses. Autophagy 2017, 13, 971-972. [CrossRef]

85. Nikoletopoulou, V.; Tavernarakis, N. Regulation and Roles of Autophagy at Synapses. Trends Cell Biol. 2018, $28,646-661$. [CrossRef]

86. Maday, S.; Holzbaur, E.L. Autophagosome biogenesis in primary neurons follows an ordered and spatially regulated pathway. Dev. Cell 2014, 30, 71-85. [CrossRef] [PubMed]

87. Jordens, I.; Fernandez-Borja, M.; Marsman, M.; Dusseljee, S.; Janssen, L.; Calafat, J.; Janssen, H.; Wubbolts, R.; Neefjes, J. The Rab7 effector protein RILP controls lysosomal transport by inducing the recruitment of dynein-dynactin motors. Curr. Biol. CB 2001, 11, 1680-1685. [CrossRef]

88. Ravikumar, B.; Acevedo-Arozena, A.; Imarisio, S.; Berger, Z.; Vacher, C.; O’Kane, C.J.; Brown, S.D.; Rubinsztein, D.C. Dynein mutations impair autophagic clearance of aggregate-prone proteins. Nat. Genet. 2005, 37, 771-776. [CrossRef] [PubMed]

89. Kimura, S.; Noda, T.; Yoshimori, T. Dynein-dependent movement of autophagosomes mediates efficient encounters with lysosomes. Cell Struct. Funct. 2008, 33, 109-122. [CrossRef]

90. Fu, M.M.; Holzbaur, E.L. JIP1 regulates the directionality of APP axonal transport by coordinating kinesin and dynein motors. J. Cell Biol. 2013, 202, 495-508. [CrossRef]

91. Fu, M.M.; Nirschl, J.J.; Holzbaur, E.L.F. LC3 binding to the scaffolding protein JIP1 regulates processive dynein-driven transport of autophagosomes. Dev. Cell 2014, 29, 577-590. [CrossRef] [PubMed]

92. Cheng, X.T.; Zhou, B.; Lin, M.Y.; Cai, Q.; Sheng, Z.H. Axonal autophagosomes recruit dynein for retrograde transport through fusion with late endosomes. J. Cell Biol. 2015, 209, 377-386. [CrossRef] [PubMed]

93. Kononenko, N.L.; Classen, G.A.; Kuijpers, M.; Puchkov, D.; Maritzen, T.; Tempes, A.; Malik, A.R.; Skalecka, A.; Bera, S.; Jaworski, J.; et al. Retrograde transport of TrkB-containing autophagosomes via the adaptor AP-2 mediates neuronal complexity and prevents neurodegeneration. Nat. Commun. 2017, 8, 14819. [CrossRef] [PubMed]

94. Soukup, S.F.; Vanhauwaert, R.; Verstreken, P. Parkinson's disease: Convergence on synaptic homeostasis. EMBO J. 2018, 37. [CrossRef]

95. Lee, S.; Sato, Y.; Nixon, R.A. Lysosomal proteolysis inhibition selectively disrupts axonal transport of degradative organelles and causes an Alzheimer's-like axonal dystrophy. J. Neurosci. 2011, 31, 7817-7830. [CrossRef]

96. Gowrishankar, S.; Yuan, P.; Wu, Y.; Schrag, M.; Paradise, S.; Grutzendler, J.; De Camilli, P.; Ferguson, S.M. Massive accumulation of luminal protease-deficient axonal lysosomes at Alzheimer's disease amyloid plaques. Proc. Natl. Acad. Sci. USA 2015, 112, E3699-E3708. [CrossRef]

97. Maday, S.; Holzbaur, E.L. Compartment-Specific Regulation of Autophagy in Primary Neurons. J. Neurosci. 2016, 36, 5933-5945. [CrossRef]

98. Maday, S.; Wallace, K.E.; Holzbaur, E.L. Autophagosomes initiate distally and mature during transport toward the cell soma in primary neurons. J. Cell Biol. 2012, 196, 407-417. [CrossRef] [PubMed] 
99. Davis, C.H.; Kim, K.Y.; Bushong, E.A.; Mills, E.A.; Boassa, D.; Shih, T.; Kinebuchi, M.; Phan, S.; Zhou, Y.; Bihlmeyer, N.A.; et al. Transcellular degradation of axonal mitochondria. Proc. Natl. Acad. Sci. USA 2014, 111, 9633-9638. [CrossRef]

100. Melentijevic, I.; Toth, M.L.; Arnold, M.L.; Guasp, R.J.; Harinath, G.; Nguyen, K.C.; Taub, D.; Parker, J.A.; Neri, C.; Gabel, C.V.; et al. C. elegans neurons jettison protein aggregates and mitochondria under neurotoxic stress. Nature 2017, 542, 367-371. [CrossRef]

101. Nicholls, R.E.; Alarcon, J.M.; Malleret, G.; Carroll, R.C.; Grody, M.; Vronskaya, S.; Kandel, E.R. Transgenic mice lacking NMDAR-dependent LTD exhibit deficits in behavioral flexibility. Neuron 2008, 58, 104-117. [CrossRef] [PubMed]

102. Luscher, C.; Malenka, R.C. NMDA receptor-dependent long-term potentiation and long-term depression (LTP/LTD). Cold Spring Harb. Perspect. Biol. 2012, 4, a005710. [CrossRef] [PubMed]

103. Shehata, M.; Matsumura, H.; Okubo-Suzuki, R.; Ohkawa, N.; Inokuchi, K. Neuronal stimulation induces autophagy in hippocampal neurons that is involved in AMPA receptor degradation after chemical long-term depression. J. Neurosci. 2012, 32, 10413-10422. [CrossRef]

104. Takeuchi, T.; Duszkiewicz, A.J.; Morris, R.G. The synaptic plasticity and memory hypothesis: Encoding, storage and persistence. Philos. Trans. R. Soc. Lond. Ser. B Biol. Sci. 2014, 369, 20130288. [CrossRef]

105. Zhao, Y.G.; Sun, L.; Miao, G.; Ji, C.; Zhao, H.; Sun, H.; Miao, L.; Yoshii, S.R.; Mizushima, N.; Wang, X.; et al. The autophagy gene Wdr45/Wipi4 regulates learning and memory function and axonal homeostasis. Autophagy 2015, 11, 881-890. [CrossRef]

106. Vitureira, N.; Goda, Y. Cell biology in neuroscience: The interplay between Hebbian and homeostatic synaptic plasticity. J. Cell Biol. 2013, 203, 175-186. [CrossRef]

107. Nikoletopoulou, V.; Sidiropoulou, K.; Kallergi, E.; Dalezios, Y.; Tavernarakis, N. Modulation of Autophagy by BDNF Underlies Synaptic Plasticity. Cell Metab. 2017, 26, 230-242.e5. [CrossRef]

108. Rowland, A.M.; Richmond, J.E.; Olsen, J.G.; Hall, D.H.; Bamber, B.A. Presynaptic terminals independently regulate synaptic clustering and autophagy of GABAA receptors in Caenorhabditis elegans. J. Neurosci. 2006, 26, 1711-1720. [CrossRef]

109. Ishibashi, K.; Uemura, T.; Waguri, S.; Fukuda, M. Atg16L1, an essential factor for canonical autophagy, participates in hormone secretion from PC12 cells independently of autophagic activity. Mol. Biol. Cell 2012, 23, 3193-3202. [CrossRef]

110. Pantoom, S.; Konstantinidis, G.; Voss, S.; Han, H.; Hofnagel, O.; Li, Z.; Wu, Y.W. RAB33B recruits the ATG16L1 complex to the phagophore via a noncanonical RAB binding protein. Autophagy 2020, 1-15. [CrossRef] [PubMed]

111. Heckmann, B.L.; Teubner, B.J.W.; Tummers, B.; Boada-Romero, E.; Harris, L.; Yang, M.; Guy, C.S.; Zakharenko, S.S.; Green, D.R. LC3-Associated Endocytosis Facilitates beta-Amyloid Clearance and Mitigates Neurodegeneration in Murine Alzheimer's Disease. Cell 2019, 178, 536-551.e14. [CrossRef]

112. Iula, L.; Keitelman, I.A.; Sabbione, F.; Fuentes, F.; Guzman, M.; Galletti, J.G.; Gerber, P.P.; Ostrowski, M.; Geffner, J.R.; Jancic, C.C.; et al. Autophagy Mediates Interleukin-1beta Secretion in Human Neutrophils. Front. Immunol. 2018, 9, 269. [CrossRef]

113. Fleming, A.; Rubinsztein, D.C. Autophagy in Neuronal Development and Plasticity. Trends Neurosci. 2020, 43, 767-779. [CrossRef]

114. Kenyon, C.J. The genetics of ageing. Nature 2010, 464, 504-512. [CrossRef]

115. Rubinsztein, D.C.; Marino, G.; Kroemer, G. Autophagy and aging. Cell 2011, 146, 682-695. [CrossRef]

116. Gelino, S.; Hansen, M. Autophagy-An Emerging Anti-Aging Mechanism. J. Clin. Exp. Pathol. 2012, 2. [CrossRef]

117. Sarkis, G.J.; Ashcom, J.D.; Hawdon, J.M.; Jacobson, L.A. Decline in protease activities with age in the nematode Caenorhabditis elegans. Mech. Ageing Dev. 1988, 45, 191-201. [CrossRef]

118. Cuervo, A.M.; Dice, J.F. How do intracellular proteolytic systems change with age? Front. Biosci. J. Virtual Libr. 1998, 3, d25-d43. [CrossRef]

119. Simonsen, A.; Cumming, R.C.; Brech, A.; Isakson, P.; Schubert, D.R.; Finley, K.D. Promoting basal levels of autophagy in the nervous system enhances longevity and oxidant resistance in adult Drosophila. Autophagy 2008, 4, 176-184. [CrossRef]

120. Demontis, F.; Perrimon, N. FOXO/4E-BP signaling in Drosophila muscles regulates organism-wide proteostasis during aging. Cell 2010, 143, 813-825. [CrossRef]

121. Kaushik, S.; Arias, E.; Kwon, H.; Lopez, N.M.; Athonvarangkul, D.; Sahu, S.; Schwartz, G.J.; Pessin, J.E.; Singh, R. Loss of autophagy in hypothalamic POMC neurons impairs lipolysis. EMBO Rep. 2012, 13, 258-265. [CrossRef]

122. Juhasz, G.; Erdi, B.; Sass, M.; Neufeld, T.P. Atg7-dependent autophagy promotes neuronal health, stress tolerance, and longevity but is dispensable for metamorphosis in Drosophila. Genes Dev. 2007, 21, 3061-3066. [CrossRef]

123. Fernandez, A.F.; Sebti, S.; Wei, Y.; Zou, Z.; Shi, M.; McMillan, K.L.; He, C.; Ting, T.; Liu, Y.; Chiang, W.C.; et al. Disruption of the beclin 1-BCL2 autophagy regulatory complex promotes longevity in mice. Nature 2018, 558, 136-140. [CrossRef]

124. Saftig, P.; Beertsen, W.; Eskelinen, E.L. LAMP-2: A control step for phagosome and autophagosome maturation. Autophagy 2008, 4, 510-512. [CrossRef]

125. Lipinski, M.M.; Zheng, B.; Lu, T.; Yan, Z.; Py, B.F.; Ng, A.; Xavier, R.J.; Li, C.; Yankner, B.A.; Scherzer, C.R.; et al. Genome-wide analysis reveals mechanisms modulating autophagy in normal brain aging and in Alzheimer's disease. Proc. Natl. Acad. Sci. USA 2010, 107, 14164-14169. [CrossRef]

126. Cuervo, A.M. Autophagy and aging: Keeping that old broom working. Trends Genet. 2008, 24, 604-612. [CrossRef]

127. Martinez-Lopez, N.; Athonvarangkul, D.; Singh, R. Autophagy and aging. Adv. Exp. Med. Biol. 2015, 847, 73-87. [CrossRef]

128. Menzies, F.M.; Fleming, A.; Rubinsztein, D.C. Compromised autophagy and neurodegenerative diseases. Nat. Rev. Neurosci. 2015, 16, 345-357. [CrossRef]

129. Loeser, R.F.; Collins, J.A.; Diekman, B.O. Ageing and the pathogenesis of osteoarthritis. Nat. Rev. Rheumatol. 2016, 12, 412-420. [CrossRef] 
130. Seluanov, A.; Mittelman, D.; Pereira-Smith, O.M.; Wilson, J.H.; Gorbunova, V. DNA end joining becomes less efficient and more error-prone during cellular senescence. Proc. Natl. Acad. Sci. USA 2004, 101, 7624-7629. [CrossRef]

131. Balaban, R.S.; Nemoto, S.; Finkel, T. Mitochondria, oxidants, and aging. Cell 2005, 120, 483-495. [CrossRef]

132. Henriques, C.M.; Ferreira, M.G. Consequences of telomere shortening during lifespan. Curr. Opin. Cell Biol. 2012, $24,804-808$. [CrossRef]

133. Sun, Y.; Coppe, J.P.; Lam, E.W. Cellular Senescence: The Sought or the Unwanted? Trends Mol. Med. 2018, 24, 871-885. [CrossRef]

134. Yao, Y.; Chinnici, C.; Tang, H.; Trojanowski, J.Q.; Lee, V.M.; Pratico, D. Brain inflammation and oxidative stress in a transgenic mouse model of Alzheimer-like brain amyloidosis. J. Neuroinflamm. 2004, 1, 21. [CrossRef]

135. Budworth, H.; Harris, F.R.; Williams, P.; Lee, D.Y.; Holt, A.; Pahnke, J.; Szczesny, B.; Acevedo-Torres, K.; Ayala-Pena, S.; McMurray, C.T. Suppression of Somatic Expansion Delays the Onset of Pathophysiology in a Mouse Model of Huntington's Disease. PLoS Genet. 2015, 11, e1005267. [CrossRef]

136. Sepe, S.; Milanese, C.; Gabriels, S.; Derks, K.W.; Payan-Gomez, C.; van, I.W.F.; Rijksen, Y.M.; Nigg, A.L.; Moreno, S.; Cerri, S.; et al. Inefficient DNA Repair Is an Aging-Related Modifier of Parkinson's Disease. Cell Rep. 2016, 15, 1866-1875. [CrossRef] [PubMed]

137. Beers, D.R.; Appel, S.H. Immune dysregulation in amyotrophic lateral sclerosis: Mechanisms and emerging therapies. Lancet Neurol. 2019, 18, 211-220. [CrossRef]

138. Amin, A.; Perera, N.D.; Beart, P.M.; Turner, B.J.; Shabanpoor, F. Amyotrophic Lateral Sclerosis and Autophagy: Dysfunction and Therapeutic Targeting. Cells 2020, 9, 2413. [CrossRef]

139. Hansen, M.; Rubinsztein, D.C.; Walker, D.W. Autophagy as a promoter of longevity: Insights from model organisms. Nat. Rev. Mol. Cell Biol. 2018, 19, 579-593. [CrossRef]

140. C. elegans Sequencing Consortium. Genome sequence of the nematode C. elegans: A platform for investigating biology. Science 1998, 282, 2012-2018. [CrossRef]

141. Kaletta, T.; Hengartner, M.O. Finding function in novel targets: C. elegans as a model organism. Nat. Rev. Drug Discov. 2006, 5, 387-398. [CrossRef] [PubMed]

142. Brenner, S. The genetics of Caenorhabditis elegans. Genetics 1974, 77, 71-94. [CrossRef]

143. Corsi, A.K.; Wightman, B.; Chalfie, M. A Transparent window into biology: A primer on Caenorhabditis elegans. Wormbook Online Rev. C. elegans Biol. 2015, 1-31. [CrossRef]

144. Anderson, J.L.; Reynolds, R.M.; Morran, L.T.; Tolman-Thompson, J.; Phillips, P.C. Experimental evolution reveals antagonistic pleiotropy in reproductive timing but not life span in Caenorhabditis elegans. J. Gerontol. Ser. A Biol. Sci. Med. Sci. 2011, 66, 1300-1308. [CrossRef] [PubMed]

145. Kourtis, N.; Tavernarakis, N. Non-developmentally programmed cell death in Caenorhabditis elegans. Semin. Cancer Biol. 2007, 17, 122-133. [CrossRef]

146. Markaki, M.; Tavernarakis, N. Caenorhabditis elegans as a model system for human diseases. Curr. Opin. Biotechnol. 2020, 63, 118-125. [CrossRef]

147. White, J.G.; Southgate, E.; Thomson, J.N.; Brenner, S. The structure of the nervous system of the nematode Caenorhabditis elegans. Philos. Trans. R. Soc. Lond. Ser. B Biol. Sci. 1986, 314, 1-340. [CrossRef]

148. Jarrell, T.A.; Wang, Y.; Bloniarz, A.E.; Brittin, C.A.; Xu, M.; Thomson, J.N.; Albertson, D.G.; Hall, D.H.; Emmons, S.W. The connectome of a decision-making neural network. Science 2012, 337, 437-444. [CrossRef]

149. Cook, S.J.; Jarrell, T.A.; Brittin, C.A.; Wang, Y.; Bloniarz, A.E.; Yakovlev, M.A.; Nguyen, K.C.Q.; Tang, L.T.; Bayer, E.A.; Duerr, J.S.; et al. Whole-animal connectomes of both Caenorhabditis elegans sexes. Nature 2019, 571, 63-71. [CrossRef] [PubMed]

150. Burglin, T.R.; Kuwabara, P.E. Homologs of the Hh signalling network in C. elegans. Wormbook Online Rev. C Elegans Biol. 2006, 1-14. [CrossRef] [PubMed]

151. Fabian, T.J.; Johnson, T.E. Production of age-synchronous mass cultures of Caenorhabditis elegans. J. Gerontol. 1994, 49 , B145-B156. [CrossRef]

152. Johnson, T.E.; McCaffrey, G. Programmed aging or error catastrophe? An examination by two-dimensional polyacrylamide gel electrophoresis. Mech. Ageing Dev. 1985, 30, 285-297. [CrossRef]

153. Lund, J.; Tedesco, P.; Duke, K.; Wang, J.; Kim, S.K.; Johnson, T.E. Transcriptional profile of aging in C. elegans. Curr. Biol. CB 2002, 12, 1566-1573. [CrossRef]

154. Wong, S.Q.; Kumar, A.V.; Mills, J.; Lapierre, L.R. C. elegans to model autophagy-related human disorders. Prog. Mol. Biol. Transl. Sci. 2020, 172, 325-373. [CrossRef] [PubMed]

155. Melendez, A.; Talloczy, Z.; Seaman, M.; Eskelinen, E.L.; Hall, D.H.; Levine, B. Autophagy genes are essential for dauer development and life-span extension in C. elegans. Science 2003, 301, 1387-1391. [CrossRef] [PubMed]

156. Jia, K.; Levine, B. Autophagy is required for dietary restriction-mediated life span extension in C. elegans. Autophagy 2007, 3, 597-599. [CrossRef]

157. Toth, M.L.; Simon, P.; Kovacs, A.L.; Vellai, T. Influence of autophagy genes on ion-channel-dependent neuronal degeneration in Caenorhabditis elegans. J. Cell Sci. 2007, 120, 1134-1141. [CrossRef]

158. Hansen, M.; Chandra, A.; Mitic, L.L.; Onken, B.; Driscoll, M.; Kenyon, C. A role for autophagy in the extension of lifespan by dietary restriction in C. elegans. PLoS Genet. 2008, 4, e24. [CrossRef]

159. Samara, C.; Syntichaki, P.; Tavernarakis, N. Autophagy is required for necrotic cell death in Caenorhabditis elegans. Cell Death Differ. 2008, 15, 105-112. [CrossRef] 
160. Toth, M.L.; Sigmond, T.; Borsos, E.; Barna, J.; Erdelyi, P.; Takacs-Vellai, K.; Orosz, L.; Kovacs, A.L.; Csikos, G.; Sass, M.; et al. Longevity pathways converge on autophagy genes to regulate life span in Caenorhabditis elegans. Autophagy 2008, 4, 330-338. [CrossRef]

161. Jia, K.; Thomas, C.; Akbar, M.; Sun, Q.; Adams-Huet, B.; Gilpin, C.; Levine, B. Autophagy genes protect against Salmonella typhimurium infection and mediate insulin signaling-regulated pathogen resistance. Proc. Natl. Acad. Sci. USA 2009, 106, 14564-14569. [CrossRef] [PubMed]

162. Tian, Y.; Li, Z.; Hu, W.; Ren, H.; Tian, E.; Zhao, Y.; Lu, Q.; Huang, X.; Yang, P.; Li, X.; et al. C. elegans screen identifies autophagy genes specific to multicellular organisms. Cell 2010, 141, 1042-1055. [CrossRef]

163. Lu, Q.; Wu, F.; Zhang, H. Aggrephagy: Lessons from C. elegans. Biochem. J. 2013, 452, 381-390. [CrossRef]

164. Zhang, H.; Chang, J.T.; Guo, B.; Hansen, M.; Jia, K.; Kovacs, A.L.; Kumsta, C.; Lapierre, L.R.; Legouis, R.; Lin, L.; et al. Guidelines for monitoring autophagy in Caenorhabditis elegans. Autophagy 2015, 11, 9-27. [CrossRef] [PubMed]

165. Chen, Y.; Scarcelli, V.; Legouis, R. Approaches for Studying Autophagy in Caenorhabditis elegans. Cells 2017, 6, 27. [CrossRef]

166. Chang, J.T.; Hansen, M.; Kumsta, C. Assessing Tissue-Specific Autophagy Flux in Adult Caenorhabditis elegans. Methods Mol. Biol. 2020, 2144, 187-200. [CrossRef] [PubMed]

167. Ogura, K.; Wicky, C.; Magnenat, L.; Tobler, H.; Mori, I.; Müller, F.; Ohshima, Y. Caenorhabditis elegans unc-51 gene required for axonal elongation encodes a novel serine/threonine kinase. Genes Dev. 1994, 8, 2389-2400. [CrossRef]

168. Tian, E.; Wang, F.; Han, J.; Zhang, H. epg-1 functions in autophagy-regulated processes and may encode a highly divergent Atg13 homolog in C. elegans. Autophagy 2009, 5, 608-615. [CrossRef]

169. Lin, L.; Yang, P.; Huang, X.; Zhang, H.; Lu, Q. The scaffold protein EPG-7 links cargo-receptor complexes with the autophagic assembly machinery. J. Cell Biol. 2013, 201, 113-129. [CrossRef]

170. Liang, Q.; Yang, P.; Tian, E.; Han, J.; Zhang, H. The C. elegans ATG101 homolog EPG-9 directly interacts with EPG-1/Atg13 and is essential for autophagy. Autophagy 2012, 8, 1426-1433. [CrossRef]

171. Yang, P.; Zhang, H. The coiled-coil domain protein EPG-8 plays an essential role in the autophagy pathway in C. elegans. Autophagy 2011, 7, 159-165. [CrossRef] [PubMed]

172. Takacs-Vellai, K.; Vellai, T.; Puoti, A.; Passannante, M.; Wicky, C.; Streit, A.; Kovacs, A.L.; Muller, F. Inactivation of the autophagy gene bec-1 triggers apoptotic cell death in C. elegans. Curr. Biol. CB 2005, 15, 1513-1517. [CrossRef]

173. Ruck, A.; Attonito, J.; Garces, K.T.; Nunez, L.; Palmisano, N.J.; Rubel, Z.; Bai, Z.; Nguyen, K.C.; Sun, L.; Grant, B.D.; et al. The Atg6/Vps30/Beclin 1 ortholog BEC-1 mediates endocytic retrograde transport in addition to autophagy in C. elegans. Autophagy 2011, 7, 386-400. [CrossRef]

174. Lapierre, L.R.; Silvestrini, M.J.; Nunez, L.; Ames, K.; Wong, S.; Le, T.T.; Hansen, M.; Melendez, A. Autophagy genes are required for normal lipid levels in C. elegans. Autophagy 2013, 9, 278-286. [CrossRef]

175. Ames, K.; Melendez, A. Non-autonomous autophagy in germline stem cell proliferation. Cell Cycle 2017, 16, 1481-1482. [CrossRef]

176. Ames, K.; Da Cunha, D.S.; Gonzalez, B.; Konta, M.; Lin, F.; Shechter, G.; Starikov, L.; Wong, S.; Bulow, H.E.; Melendez, A. A Non-Cell-Autonomous Role of BEC-1/BECN1/Beclin1 in Coordinating Cell-Cycle Progression and Stem Cell Proliferation during Germline Development. Curr. Biol. CB 2017, 27, 905-913. [CrossRef]

177. Lowry, J.; Yochem, J.; Chuang, C.H.; Sugioka, K.; Connolly, A.A.; Bowerman, B. High-Throughput Cloning of TemperatureSensitive Caenorhabditis elegans Mutants with Adult Syncytial Germline Membrane Architecture Defects. G3 2015, 5, $2241-2255$. [CrossRef] [PubMed]

178. Roggo, L.; Bernard, V.; Kovacs, A.L.; Rose, A.M.; Savoy, F.; Zetka, M.; Wymann, M.P.; Muller, F. Membrane transport in Caenorhabditis elegans: An essential role for VPS34 at the nuclear membrane. EMBO J. 2002, 21, 1673-1683. [CrossRef]

179. Lu, Q.; Yang, P.; Huang, X.; Hu, W.; Guo, B.; Wu, F.; Lin, L.; Kovacs, A.L.; Yu, L.; Zhang, H. The WD40 repeat PtdIns(3)P-binding protein EPG-6 regulates progression of omegasomes to autophagosomes. Dev. Cell 2011, 21, 343-357. [CrossRef] [PubMed]

180. Guo, B.; Huang, X.; Zhang, P.; Qi, L.; Liang, Q.; Zhang, X.; Huang, J.; Fang, B.; Hou, W.; Han, J.; et al. Genome-wide screen identifies signaling pathways that regulate autophagy during Caenorhabditis elegans development. EMBO Rep. 2014, 15, 705-713.

181. Minnerly, J.; Zhang, J.; Parker, T.; Kaul, T.; Jia, K. The cell non-autonomous function of ATG-18 is essential for neuroendocrine regulation of Caenorhabditis elegans lifespan. PLoS Genet. 2017, 13, e1006764. [CrossRef]

182. Zhang, H.; Wu, F.; Wang, X.; Du, H. The two C. elegans ATG-16 homologs have partially redundant functions in the basal autophagy pathway. Autophagy 2013, 9, 1965-1974. [CrossRef]

183. Zhang, Y.; Yan, L.; Zhou, Z.; Yang, P.; Tian, E.; Zhang, K.; Zhao, Y.; Li, Z.; Song, B.; Han, J.; et al. SEPA-1 mediates the specific recognition and degradation of P granule components by autophagy in C. elegans. Cell 2009, 136, 308-321. [CrossRef] [PubMed]

184. Wu, F.; Li, Y.; Wang, F.; Noda, N.N.; Zhang, H. Differential function of the two Atg4 homologues in the aggrephagy pathway in Caenorhabditis elegans. J. Biol. Chem. 2012, 287, 29457-29467. [CrossRef] [PubMed]

185. Hashimoto, Y.; Ookuma, S.; Nishida, E. Lifespan extension by suppression of autophagy genes in Caenorhabditis elegans. Genes Cells Devoted Mol. Cell. Mech. 2009, 14, 717-726. [CrossRef] [PubMed]

186. Alberti, A.; Michelet, X.; Djeddi, A.; Legouis, R. The autophagosomal protein LGG-2 acts synergistically with LGG-1 in dauer formation and longevity in C. elegans. Autophagy 2010, 6, 622-633. [CrossRef]

187. Manil-Segalen, M.; Lefebvre, C.; Jenzer, C.; Trichet, M.; Boulogne, C.; Satiat-Jeunemaitre, B.; Legouis, R. The C. elegans LC3 acts downstream of GABARAP to degrade autophagosomes by interacting with the HOPS subunit VPS39. Dev. Cell 2014, $28,43-55$. [CrossRef] 
188. Kostich, M.; Fire, A.; Fambrough, D.M. Identification and molecular-genetic characterization of a LAMP/CD68-like protein from Caenorhabditis elegans. J. Cell Sci. 2000, 113 Pt 14, 2595-2606.

189. Nilsson, L.; Jonsson, E.; Tuck, S. Caenorhabditis elegans numb inhibits endocytic recycling by binding TAT-1 aminophospholipid translocase. Traffic 2011, 12, 1839-1849. [CrossRef]

190. Sato, M.; Saegusa, K.; Sato, K.; Hara, T.; Harada, A. Caenorhabditis elegans SNAP-29 is required for organellar integrity of the endomembrane system and general exocytosis in intestinal epithelial cells. Mol. Biol. Cell 2011, 22, 2579-2587. [CrossRef]

191. Wilkinson, D.S.; Jariwala, J.S.; Anderson, E.; Mitra, K.; Meisenhelder, J.; Chang, J.T.; Ideker, T.; Hunter, T.; Nizet, V.; Dillin, A.; et al. Phosphorylation of LC3 by the Hippo kinases STK3/STK4 is essential for autophagy. Mol. Cell 2015, 57, 55-68. [CrossRef]

192. Vellai, T.; Takacs-Vellai, K.; Zhang, Y.; Kovacs, A.L.; Orosz, L.; Müller, F. Genetics: Influence of TOR kinase on lifespan in C elegans. Nature 2003, 426, 620. [CrossRef] [PubMed]

193. Jia, K.; Chen, D.; Riddle, D.L. The TOR pathway interacts with the insulin signaling pathway to regulate C. elegans larval development, metabolism and life span. Development 2004, 131, 3897-3906. [CrossRef]

194. Hermann, G.J.; Schroeder, L.K.; Hieb, C.A.; Kershner, A.M.; Rabbitts, B.M.; Fonarev, P.; Grant, B.D.; Priess, J.R. Genetic analysis of lysosomal trafficking in Caenorhabditis elegans. Mol. Biol. Cell 2005, 16, 3273-3288. [CrossRef] [PubMed]

195. Al Rawi, S.; Louvet-Vallee, S.; Djeddi, A.; Sachse, M.; Culetto, E.; Hajjar, C.; Boyd, L.; Legouis, R.; Galy, V. Postfertilization autophagy of sperm organelles prevents paternal mitochondrial DNA transmission. Science 2011, 334, 1144-1147. [CrossRef]

196. Sato, M.; Sato, K. Degradation of paternal mitochondria by fertilization-triggered autophagy in C. elegans embryos. Science 2011, 334, 1141-1144. [CrossRef]

197. Hansen, M.; Taubert, S.; Crawford, D.; Libina, N.; Lee, S.J.; Kenyon, C. Lifespan extension by conditions that inhibit translation in Caenorhabditis elegans. Aging Cell 2007, 6, 95-110. [CrossRef] [PubMed]

198. Palmisano, N.J.; Rosario, N.; Wysocki, M.; Hong, M.; Grant, B.; Melendez, A. The recycling endosome protein RAB-10 promotes autophagic flux and localization of the transmembrane protein ATG-9. Autophagy 2017, 13, 1742-1753. [CrossRef]

199. Conway, O.; Akpinar, H.A.; Rogov, V.V.; Kirkin, V. Selective Autophagy Receptors in Neuronal Health and Disease. J. Mol. Biol. 2020, 432, 2483-2509. [CrossRef] [PubMed]

200. Schmeisser, K.; Parker, J.A. Pleiotropic Effects of mTOR and Autophagy During Development and Aging. Front. Cell Dev. Biol. 2019, 7, 192. [CrossRef]

201. Chang, J.T.; Kumsta, C.; Hellman, A.B.; Adams, L.M.; Hansen, M. Spatiotemporal regulation of autophagy during Caenorhabditis elegans aging. eLife 2017, 6, e18459. [CrossRef]

202. Hars, E.S.; Qi, H.; Ryazanov, A.G.; Jin, S.; Cai, L.; Hu, C.; Liu, L.F. Autophagy regulates ageing in C. elegans. Autophagy 2007, 3, 93-95. [CrossRef]

203. Lapierre, L.R.; Gelino, S.; Melendez, A.; Hansen, M. Autophagy and lipid metabolism coordinately modulate life span in germline-less C. elegans. Curr. Biol. CB 2011, 21, 1507-1514. [CrossRef]

204. Lapierre, L.R.; De Magalhaes Filho, C.D.; McQuary, P.R.; Chu, C.C.; Visvikis, O.; Chang, J.T.; Gelino, S.; Ong, B.; Davis, A.E.; Irazoqui, J.E.; et al. The TFEB orthologue HLH-30 regulates autophagy and modulates longevity in Caenorhabditis elegans. Nat. Commun. 2013, 4, 2267. [CrossRef]

205. Mammucari, C.; Milan, G.; Romanello, V.; Masiero, E.; Rudolf, R.; Del Piccolo, P.; Burden, S.J.; Di Lisi, R.; Sandri, C.; Zhao, J.; et al. FoxO3 Controls Autophagy in Skeletal Muscle In Vivo. Cell Metab. 2007, 6, 458-471. [CrossRef] [PubMed]

206. Zhao, J.; Brault, J.J.; Schild, A.; Cao, P.; Sandri, M.; Schiaffino, S.; Lecker, S.H.; Goldberg, A.L. FoxO3 Coordinately Activates Protein Degradation by the Autophagic/Lysosomal and Proteasomal Pathways in Atrophying Muscle Cells. Cell Metab. 2007, 6, 472-483. [CrossRef]

207. Wilhelm, T.; Byrne, J.; Medina, R.; Kolundzic, E.; Geisinger, J.; Hajduskova, M.; Tursun, B.; Richly, H. Neuronal inhibition of the autophagy nucleation complex extends life span in post-reproductive C. elegans. Genes Dev. 2017, 31, 1561-1572. [CrossRef] [PubMed]

208. Gwinn, D.M.; Shackelford, D.B.; Egan, D.F.; Mihaylova, M.M.; Mery, A.; Vasquez, D.S.; Turk, B.E.; Shaw, R.J. AMPK phosphorylation of raptor mediates a metabolic checkpoint. Mol. Cell 2008, 30, 214-226. [CrossRef]

209. Hardie, D.G.; Ross, F.A.; Hawley, S.A. AMPK: A nutrient and energy sensor that maintains energy homeostasis. Nat. Rev. Mol. Cell Biol. 2012, 13, 251-262. [CrossRef]

210. Hardie, D.G. AMPK and autophagy get connected. EMBO J. 2011, 30, 634-635. [CrossRef] [PubMed]

211. Egan, D.F.; Shackelford, D.B.; Mihaylova, M.M.; Gelino, S.; Kohnz, R.A.; Mair, W.; Vasquez, D.S.; Joshi, A.; Gwinn, D.M.; Taylor, R.; et al. Phosphorylation of ULK1 (hATG1) by AMP-activated protein kinase connects energy sensing to mitophagy. Science 2011, 331, 456-461. [CrossRef]

212. Kim, J.; Kundu, M.; Viollet, B.; Guan, K.L. AMPK and mTOR regulate autophagy through direct phosphorylation of Ulk1. Nat. Cell Biol. 2011, 13, 132-141. [CrossRef]

213. Burkewitz, K.; Zhang, Y.; Mair, W.B. AMPK at the nexus of energetics and aging. Cell Metab. 2014, 20, 10-25. [CrossRef] [PubMed]

214. Apfeld, J.; O'Connor, G.; McDonagh, T.; DiStefano, P.S.; Curtis, R. The AMP-activated protein kinase AAK-2 links energy levels and insulin-like signals to lifespan in C. elegans. Genes Dev. 2004, 18, 3004-3009. [CrossRef]

215. Greer, E.L.; Dowlatshahi, D.; Banko, M.R.; Villen, J.; Hoang, K.; Blanchard, D.; Gygi, S.P.; Brunet, A. An AMPK-FOXO pathway mediates longevity induced by a novel method of dietary restriction in C. elegans. Curr. Biol. CB 2007, 17, 1646-1656. [CrossRef] 
216. Greer, E.L.; Brunet, A. Different dietary restriction regimens extend lifespan by both independent and overlapping genetic pathways in C. elegans. Aging Cell 2009, 8, 113-127. [CrossRef] [PubMed]

217. Mair, W.; Morantte, I.; Rodrigues, A.P.; Manning, G.; Montminy, M.; Shaw, R.J.; Dillin, A. Lifespan extension induced by AMPK and calcineurin is mediated by CRTC-1 and CREB. Nature 2011, 470, 404-408. [CrossRef]

218. Chen, D.; Li, P.W.; Goldstein, B.A.; Cai, W.; Thomas, E.L.; Chen, F.; Hubbard, A.E.; Melov, S.; Kapahi, P. Germline signaling mediates the synergistically prolonged longevity produced by double mutations in daf-2 and rsks-1 in C. elegans. Cell Rep. 2013, 5, 1600-1610. [CrossRef]

219. Bishop, N.A.; Guarente, L. Two neurons mediate diet-restriction-induced longevity in C. elegans. Nature 2007, 447, 545-549. [CrossRef]

220. Schmeisser, K.; Parker, J.A. Nicotinamide-N-methyltransferase controls behavior, neurodegeneration and lifespan by regulating neuronal autophagy. PLoS Genet. 2018, 14, e1007561. [CrossRef] [PubMed]

221. Thomas, M.G.; Saldanha, M.; Mistry, R.J.; Dexter, D.T.; Ramsden, D.B.; Parsons, R.B. Nicotinamide N-methyltransferase expression in SH-SY5Y neuroblastoma and N27 mesencephalic neurones induces changes in cell morphology via ephrin-B2 and Akt signalling. Cell Death Dis. 2013, 4, e669. [CrossRef]

222. Liu, K.Y.; Mistry, R.J.; Aguirre, C.A.; Fasouli, E.S.; Thomas, M.G.; Klamt, F.; Ramsden, D.B.; Parsons, R.B. Nicotinamide Nmethyltransferase increases complex I activity in SH-SY5Y cells via sirtuin 3. Biochem. Biophys. Res. Commun. 2015, 467, 491-496. [CrossRef]

223. Ulanovskaya, O.A.; Zuhl, A.M.; Cravatt, B.F. NNMT promotes epigenetic remodeling in cancer by creating a metabolic methylation sink. Nat. Chem. Biol. 2013, 9, 300-306. [CrossRef] [PubMed]

224. Matsunaga, K.; Saitoh, T.; Tabata, K.; Omori, H.; Satoh, T.; Kurotori, N.; Maejima, I.; Shirahama-Noda, K.; Ichimura, T.; Isobe, T.; et al. Two Beclin 1-binding proteins, Atg14L and Rubicon, reciprocally regulate autophagy at different stages. Nat. Cell Biol. 2009, 11, 385-396. [CrossRef]

225. Zhong, Y.; Wang, Q.J.; Li, X.; Yan, Y.; Backer, J.M.; Chait, B.T.; Heintz, N.; Yue, Z. Distinct regulation of autophagic activity by Atg14L and Rubicon associated with Beclin 1-phosphatidylinositol-3-kinase complex. Nat. Cell Biol. 2009, 11, 468-476. [CrossRef]

226. Nakamura, S.; Oba, M.; Suzuki, M.; Takahashi, A.; Yamamuro, T.; Fujiwara, M.; Ikenaka, K.; Minami, S.; Tabata, N.; Yamamoto, K.; et al. Suppression of autophagic activity by Rubicon is a signature of aging. Nat. Commun. 2019, 10, 847. [CrossRef] [PubMed]

227. Kimura, K.D.; Tissenbaum, H.A.; Liu, Y.; Ruvkun, G. daf-2, an insulin receptor-like gene that regulates longevity and diapause in Caenorhabditis elegans. Science 1997, 277, 942-946. [CrossRef]

228. Lin, K.; Dorman, J.B.; Rodan, A.; Kenyon, C. daf-16: An HNF-3/forkhead family member that can function to double the life-span of Caenorhabditis elegans. Science 1997, 278, 1319-1322. [CrossRef] [PubMed]

229. Ogg, S.; Paradis, S.; Gottlieb, S.; Patterson, G.I.; Lee, L.; Tissenbaum, H.A.; Ruvkun, G. The Fork head transcription factor DAF-16 transduces insulin-like metabolic and longevity signals in C. elegans. Nature 1997, 389, 994-999. [CrossRef] [PubMed]

230. Kimura, S.; Noda, T.; Yoshimori, T. Dissection of the autophagosome maturation process by a novel reporter protein, tandem fluorescent-tagged LC3. Autophagy 2007, 3, 452-460. [CrossRef]

231. Chapin, H.C.; Okada, M.; Merz, A.J.; Miller, D.L. Tissue-specific autophagy responses to aging and stress in C. elegans. Aging 2015, 7, 419-434. [CrossRef]

232. Komatsu, M.; Wang, Q.J.; Holstein, G.R.; Friedrich, V.L., Jr.; Iwata, J.; Kominami, E.; Chait, B.T.; Tanaka, K.; Yue, Z. Essential role for autophagy protein Atg7 in the maintenance of axonal homeostasis and the prevention of axonal degeneration. Proc. Natl. Acad. Sci. USA 2007, 104, 14489-14494. [CrossRef]

233. Nishiyama, J.; Miura, E.; Mizushima, N.; Watanabe, M.; Yuzaki, M. Aberrant membranes and double-membrane structures accumulate in the axons of Atg5-null Purkinje cells before neuronal death. Autophagy 2007, 3, 591-596. [CrossRef]

234. Maday, S. Mechanisms of neuronal homeostasis: Autophagy in the axon. Brain Res. 2016, 1649, 143-150. [CrossRef] [PubMed]

235. Wang, Y.; Song, M.; Song, F. Neuronal autophagy and axon degeneration. Cell. Mol. Life Sci. 2018, 75, 2389-2406. [CrossRef]

236. Kanno, H.; Ozawa, H.; Sekiguchi, A.; Itoi, E. The role of autophagy in spinal cord injury. Autophagy 2009, 5, 390-392. [CrossRef] [PubMed]

237. Rodriguez-Muela, N.; Boya, P. Axonal damage, autophagy and neuronal survival. Autophagy 2012, 8, 286-288. [CrossRef]

238. Lipinski, M.M.; Wu, J.; Faden, A.I.; Sarkar, C. Function and Mechanisms of Autophagy in Brain and Spinal Cord Trauma. Antioxid. Redox Signal. 2015, 23, 565-577. [CrossRef] [PubMed]

239. He, Z.; Jin, Y. Intrinsic Control of Axon Regeneration. Neuron 2016, 90, 437-451. [CrossRef]

240. He, M.; Ding, Y.; Chu, C.; Tang, J.; Xiao, Q.; Luo, Z.G. Autophagy induction stabilizes microtubules and promotes axon regeneration after spinal cord injury. Proc. Natl. Acad. Sci. USA 2016, 113, 11324-11329. [CrossRef]

241. Saraswat Ohri, S.; Bankston, A.N.; Mullins, S.A.; Liu, Y.; Andres, K.R.; Beare, J.E.; Howard, R.M.; Burke, D.A.; Riegler, A.S.; Smith, A.E.; et al. Blocking Autophagy in Oligodendrocytes Limits Functional Recovery after Spinal Cord Injury. J. Neurosci. 2018, 38, 5900-5912. [CrossRef] [PubMed]

242. Bargmann, C.I.; Avery, L. Laser killing of cells in Caenorhabditis elegans. Methods Cell Biol. 1995, 48, 225-250. [CrossRef]

243. Yanik, M.F.; Cinar, H.; Cinar, H.N.; Chisholm, A.D.; Jin, Y.; Ben-Yakar, A. Neurosurgery: Functional regeneration after laser axotomy. Nature 2004, 432, 822. [CrossRef]

244. Chung, S.H.; Clark, D.A.; Gabel, C.V.; Mazur, E.; Samuel, A.D. The role of the AFD neuron in C. elegans thermotaxis analyzed using femtosecond laser ablation. BMC Neurosci. 2006, 7, 30. [CrossRef] 
245. Wu, Z.; Ghosh-Roy, A.; Yanik, M.F.; Zhang, J.Z.; Jin, Y.; Chisholm, A.D. Caenorhabditis elegans neuronal regeneration is influenced by life stage, ephrin signaling, and synaptic branching. Proc. Natl. Acad. Sci. USA 2007, 104, 15132-15137. [CrossRef] [PubMed]

246. Ko, S.H.; Apple, E.C.; Liu, Z.; Chen, L. Age-dependent autophagy induction after injury promotes axon regeneration by limiting NOTCH. Autophagy 2020, 16, 2052-2068. [CrossRef] [PubMed]

247. Chen, L.; Wang, Z.; Ghosh-Roy, A.; Hubert, T.; Yan, D.; O’Rourke, S.; Bowerman, B.; Wu, Z.; Jin, Y.; Chisholm, A.D. Axon regeneration pathways identified by systematic genetic screening in C. elegans. Neuron 2011, 71, 1043-1057. [CrossRef]

248. El Bejjani, R.; Hammarlund, M. Notch signaling inhibits axon regeneration. Neuron 2012, 73, 268-278. [CrossRef] [PubMed]

249. Feleciano, D.R.; Juenemann, K.; Iburg, M.; Bras, I.C.; Holmberg, C.I.; Kirstein, J. Crosstalk Between Chaperone-Mediated Protein Disaggregation and Proteolytic Pathways in Aging and Disease. Front. Aging Neurosci. 2019, 11, 9. [CrossRef]

250. Wei, C.C.; Chang, C.H.; Liao, V.H. Anti-Parkinsonian effects of beta-amyrin are regulated via LGG-1 involved autophagy pathway in Caenorhabditis elegans. Phytomed. Int. J. Phytother. Phytopharm. 2017, 36, 118-125. [CrossRef]

251. Kumsta, C.; Chang, J.T.; Lee, R.; Tan, E.P.; Yang, Y.; Loureiro, R.; Choy, E.H.; Lim, S.H.Y.; Saez, I.; Springhorn, A.; et al. The autophagy receptor p62/SQST-1 promotes proteostasis and longevity in C. elegans by inducing autophagy. Nat. Commun. 2019, 10, 5648. [CrossRef] [PubMed]

252. Kumsta, C.; Chang, J.T.; Schmalz, J.; Hansen, M. Hormetic heat stress and HSF-1 induce autophagy to improve survival and proteostasis in C. elegans. Nat. Commun. 2017, 8, 14337. [CrossRef] [PubMed]

253. Stavoe, A.K.; Hill, S.E.; Hall, D.H.; Colon-Ramos, D.A. KIF1A/UNC-104 Transports ATG-9 to Regulate Neurodevelopment and Autophagy at Synapses. Dev. Cell 2016, 38, 171-185. [CrossRef]

254. Crawley, O.; Opperman, K.J.; Desbois, M.; Adrados, I.; Borgen, M.A.; Giles, A.C.; Duckett, D.R.; Grill, B. Autophagy is inhibited by ubiquitin ligase activity in the nervous system. Nat. Commun. 2019, 10, 5017. [CrossRef] [PubMed]

255. Ravikumar, B.; Vacher, C.; Berger, Z.; Davies, J.E.; Luo, S.; Oroz, L.G.; Scaravilli, F.; Easton, D.F.; Duden, R.; O’Kane, C.J.; et al. Inhibition of mTOR induces autophagy and reduces toxicity of polyglutamine expansions in fly and mouse models of Huntington disease. Nat. Genet. 2004, 36, 585-595. [CrossRef] [PubMed]

256. Berger, Z.; Ravikumar, B.; Menzies, F.M.; Oroz, L.G.; Underwood, B.R.; Pangalos, M.N.; Schmitt, I.; Wullner, U.; Evert, B.O.; O'Kane, C.J.; et al. Rapamycin alleviates toxicity of different aggregate-prone proteins. Hum. Mol. Genet. 2006, 15, 433-442. [CrossRef] [PubMed]

257. Mizushima, N.; Levine, B.; Cuervo, A.M.; Klionsky, D.J. Autophagy fights disease through cellular self-digestion. Nature 2008, 451, 1069-1075. [CrossRef] [PubMed]

258. Mandrioli, J.; D'Amico, R.; Zucchi, E.; Gessani, A.; Fini, N.; Fasano, A.; Caponnetto, C.; Chio, A.; Dalla Bella, E.; Lunetta, C.; et al. Rapamycin treatment for amyotrophic lateral sclerosis: Protocol for a phase II randomized, double-blind, placebo-controlled, multicenter, clinical trial (RAP-ALS trial). Medicine 2018, 97, e11119. [CrossRef]

259. Fatouros, C.; Pir, G.J.; Biernat, J.; Koushika, S.P.; Mandelkow, E.; Mandelkow, E.M.; Schmidt, E.; Baumeister, R. Inhibition of tau aggregation in a novel Caenorhabditis elegans model of tauopathy mitigates proteotoxicity. Hum. Mol. Genet. 2012, 21, 3587-3603. [CrossRef]

260. Ko, S.H.; Gonzalez, G.; Liu, Z.; Chen, L. Axon Injury-Induced Autophagy Activation Is Impaired in a C. elegans Model of Tauopathy. Int. J. Mol. Sci. 2020, 21, 8559. [CrossRef]

261. Congdon, E.E.; Wu, J.W.; Myeku, N.; Figueroa, Y.H.; Herman, M.; Marinec, P.S.; Gestwicki, J.E.; Dickey, C.A.; Yu, W.H.; Duff, K.E. Methylthioninium chloride (methylene blue) induces autophagy and attenuates tauopathy in vitro and in vivo. Autophagy 2012, 8, 609-622. [CrossRef] [PubMed]

262. Kruger, U.; Wang, Y.; Kumar, S.; Mandelkow, E.M. Autophagic degradation of tau in primary neurons and its enhancement by trehalose. Neurobiol. Aging 2012, 33, 2291-2305. [CrossRef] [PubMed]

263. Schaeffer, V.; Lavenir, I.; Ozcelik, S.; Tolnay, M.; Winkler, D.T.; Goedert, M. Stimulation of autophagy reduces neurodegeneration in a mouse model of human tauopathy. Brain J. Neurol. 2012, 135, 2169-2177. [CrossRef]

264. Ozcelik, S.; Fraser, G.; Castets, P.; Schaeffer, V.; Skachokova, Z.; Breu, K.; Clavaguera, F.; Sinnreich, M.; Kappos, L.; Goedert, M.; et al. Rapamycin attenuates the progression of tau pathology in P301S tau transgenic mice. PLoS ONE 2013, 8, e62459. [CrossRef] [PubMed]

265. Siman, R.; Cocca, R.; Dong, Y. The mTOR Inhibitor Rapamycin Mitigates Perforant Pathway Neurodegeneration and Synapse Loss in a Mouse Model of Early-Stage Alzheimer-Type Tauopathy. PLoS ONE 2015, 10, e0142340. [CrossRef]

266. Kim, S.; Choi, K.J.; Cho, S.J.; Yun, S.M.; Jeon, J.P.; Koh, Y.H.; Song, J.; Johnson, G.V.; Jo, C. Fisetin stimulates autophagic degradation of phosphorylated tau via the activation of TFEB and Nrf2 transcription factors. Sci. Rep. 2016, 6, 24933. [CrossRef]

267. Lin, A.L.; Jahrling, J.B.; Zhang, W.; DeRosa, N.; Bakshi, V.; Romero, P.; Galvan, V.; Richardson, A. Rapamycin rescues vascular, metabolic and learning deficits in apolipoprotein E4 transgenic mice with pre-symptomatic Alzheimer's disease. J. Cereb. Blood Flow Metab. 2017, 37, 217-226. [CrossRef]

268. Lim, F.; Hernandez, F.; Lucas, J.J.; Gomez-Ramos, P.; Moran, M.A.; Avila, J. FTDP-17 mutations in tau transgenic mice provoke lysosomal abnormalities and Tau filaments in forebrain. Mol. Cell. Neurosci. 2001, 18, 702-714. [CrossRef]

269. Wang, Y.; Mandelkow, E. Degradation of tau protein by autophagy and proteasomal pathways. Biochem. Soc. Trans. 2012, 40, 644-652. [CrossRef]

270. Hall, A.; Lalli, G. Rho and Ras GTPases in axon growth, guidance, and branching. Cold Spring Harb. Perspect. Biol. 2010, 2, a001818. [CrossRef] [PubMed] 
271. Kim, H.; Calatayud, C.; Guha, S.; Fernandez-Carasa, I.; Berkowitz, L.; Carballo-Carbajal, I.; Ezquerra, M.; Fernandez-Santiago, R.; Kapahi, P.; Raya, A.; et al. The Small GTPase RAC1/CED-10 Is Essential in Maintaining Dopaminergic Neuron Function and Survival Against alpha-Synuclein-Induced Toxicity. Mol. Neurobiol. 2018, 55, 7533-7552. [CrossRef]

272. Stephan, A.H.; Madison, D.V.; Mateos, J.M.; Fraser, D.A.; Lovelett, E.A.; Coutellier, L.; Kim, L.; Tsai, H.H.; Huang, E.J.; Rowitch, D.H.; et al. A dramatic increase of C1q protein in the CNS during normal aging. J. Neurosci. 2013, 33, 13460-13474. [CrossRef]

273. Hill, J.M.; Clement, C.; Pogue, A.I.; Bhattacharjee, S.; Zhao, Y.; Lukiw, W.J. Pathogenic microbes, the microbiome, and Alzheimer's disease (AD). Front. Aging Neurosci. 2014, 6, 127. [CrossRef]

274. Sekar, A.; Bialas, A.R.; de Rivera, H.; Davis, A.; Hammond, T.R.; Kamitaki, N.; Tooley, K.; Presumey, J.; Baum, M.; Van Doren, V.; et al. Schizophrenia risk from complex variation of complement component 4. Nature 2016, 530, 177-183. [CrossRef] [PubMed]

275. Hickman, S.E.; Kingery, N.D.; Ohsumi, T.K.; Borowsky, M.L.; Wang, L.C.; Means, T.K.; El Khoury, J. The microglial sensome revealed by direct RNA sequencing. Nat. Neurosci. 2013, 16, 1896-1905. [CrossRef] [PubMed]

276. Williams, W.M.; Torres, S.; Siedlak, S.L.; Castellani, R.J.; Perry, G.; Smith, M.A.; Zhu, X. Antimicrobial peptide beta-defensin-1 expression is upregulated in Alzheimer's brain. J. Neuroinflamm. 2013, 10, 127. [CrossRef] [PubMed]

277. Lezi, E.; Zhou, T.; Koh, S.; Chuang, M.; Sharma, R.; Pujol, N.; Chisholm, A.D.; Eroglu, C.; Matsunami, H.; Yan, D. An Antimicrobial Peptide and Its Neuronal Receptor Regulate Dendrite Degeneration in Aging and Infection. Neuron 2018, 97, 125-138.e5. [CrossRef]

278. Eisenberg, T.; Knauer, H.; Schauer, A.; Buttner, S.; Ruckenstuhl, C.; Carmona-Gutierrez, D.; Ring, J.; Schroeder, S.; Magnes, C.; Antonacci, L.; et al. Induction of autophagy by spermidine promotes longevity. Nat. Cell Biol. 2009, 11, 1305-1314. [CrossRef] [PubMed]

279. Vijayan, B.; Raj, V.; Nandakumar, S.; Kishore, A.; Thekkuveettil, A. Spermine protects alpha-synuclein expressing dopaminergic neurons from manganese-induced degeneration. Cell Biol. Toxicol. 2019, 35, 147-159. [CrossRef]

280. Settembre, C.; Di Malta, C.; Polito, V.A.; Garcia Arencibia, M.; Vetrini, F.; Erdin, S.; Erdin, S.U.; Huynh, T.; Medina, D.; Colella, P.; et al. TFEB links autophagy to lysosomal biogenesis. Science 2011, 332, 1429-1433. [CrossRef] [PubMed]

281. Decressac, M.; Mattsson, B.; Weikop, P.; Lundblad, M.; Jakobsson, J.; Bjorklund, A. TFEB-mediated autophagy rescues midbrain dopamine neurons from alpha-synuclein toxicity. Proc. Natl. Acad. Sci. USA 2013, 110, E1817-E1826. [CrossRef] [PubMed]

282. Martini-Stoica, H.; Xu, Y.; Ballabio, A.; Zheng, H. The Autophagy-Lysosomal Pathway in Neurodegeneration: A TFEB Perspective. Trends Neurosci. 2016, 39, 221-234. [CrossRef] [PubMed]

283. Torra, A.; Parent, A.; Cuadros, T.; Rodriguez-Galvan, B.; Ruiz-Bronchal, E.; Ballabio, A.; Bortolozzi, A.; Vila, M.; Bove, J. Overexpression of TFEB Drives a Pleiotropic Neurotrophic Effect and Prevents Parkinson's Disease-Related Neurodegeneration. Mol. Ther. J. Am. Soc. Gene Ther. 2018, 26, 1552-1567. [CrossRef]

284. Cortes, C.J.; La Spada, A.R. TFEB dysregulation as a driver of autophagy dysfunction in neurodegenerative disease: Molecular mechanisms, cellular processes, and emerging therapeutic opportunities. Neurobiol. Dis. 2019, 122, 83-93. [CrossRef]

285. Baker, M.; Mackenzie, I.R.; Pickering-Brown, S.M.; Gass, J.; Rademakers, R.; Lindholm, C.; Snowden, J.; Adamson, J.; Sadovnick, A.D.; Rollinson, S.; et al. Mutations in progranulin cause tau-negative frontotemporal dementia linked to chromosome 17. Nature 2006, 442, 916-919. [CrossRef]

286. Cruts, M.; Gijselinck, I.; van der Zee, J.; Engelborghs, S.; Wils, H.; Pirici, D.; Rademakers, R.; Vandenberghe, R.; Dermaut, B.; Martin, J.J.; et al. Null mutations in progranulin cause ubiquitin-positive frontotemporal dementia linked to chromosome $17 \mathrm{q} 21$. Nature 2006, 442, 920-924. [CrossRef]

287. Neumann, M.; Sampathu, D.M.; Kwong, L.K.; Truax, A.C.; Micsenyi, M.C.; Chou, T.T.; Bruce, J.; Schuck, T.; Grossman, M.; Clark, C.M.; et al. Ubiquitinated TDP-43 in frontotemporal lobar degeneration and amyotrophic lateral sclerosis. Science 2006, 314, 130-133. [CrossRef] [PubMed]

288. Smith, K.R.; Damiano, J.; Franceschetti, S.; Carpenter, S.; Canafoglia, L.; Morbin, M.; Rossi, G.; Pareyson, D.; Mole, S.E.; Staropoli, J.F.; et al. Strikingly different clinicopathological phenotypes determined by progranulin-mutation dosage. Am. J. Hum. Genet. 2012, 90, 1102-1107. [CrossRef]

289. Butler, V.J.; Gao, F.; Corrales, C.I.; Cortopassi, W.A.; Caballero, B.; Vohra, M.; Ashrafi, K.; Cuervo, A.M.; Jacobson, M.P.; Coppola, G.; et al. Age- and stress-associated C. elegans granulins impair lysosomal function and induce a compensatory HLH-30/TFEB transcriptional response. PLoS Genet. 2019, 15, e1008295. [CrossRef]

290. Markaki, M.; Palikaras, K.; Tavernarakis, N. Novel Insights Into the Anti-aging Role of Mitophagy. Int. Rev. Cell Mol. Biol. 2018, 340, 169-208. [CrossRef]

291. Lou, G.; Palikaras, K.; Lautrup, S.; Scheibye-Knudsen, M.; Tavernarakis, N.; Fang, E.F. Mitophagy and Neuroprotection. Trends Mol. Med. 2020, 26, 8-20. [CrossRef]

292. Palikaras, K.; Tavernarakis, N. Regulation and roles of mitophagy at synapses. Mech. Ageing Dev. 2020, 187, 111216. [CrossRef] [PubMed]

293. Lustbader, J.W.; Cirilli, M.; Lin, C.; Xu, H.W.; Takuma, K.; Wang, N.; Caspersen, C.; Chen, X.; Pollak, S.; Chaney, M.; et al. ABAD directly links Abeta to mitochondrial toxicity in Alzheimer's disease. Science 2004, 304, 448-452. [CrossRef]

294. Scheibye-Knudsen, M.; Fang, E.F.; Croteau, D.L.; Wilson, D.M., 3rd; Bohr, V.A. Protecting the mitochondrial powerhouse. Trends Cell Biol. 2015, 25, 158-170. [CrossRef]

295. Kerr, J.S.; Adriaanse, B.A.; Greig, N.H.; Mattson, M.P.; Cader, M.Z.; Bohr, V.A.; Fang, E.F. Mitophagy and Alzheimer's Disease: Cellular and Molecular Mechanisms. Trends Neurosci. 2017, 40, 151-166. [CrossRef] [PubMed] 
296. Fang, E.F.; Hou, Y.; Palikaras, K.; Adriaanse, B.A.; Kerr, J.S.; Yang, B.; Lautrup, S.; Hasan-Olive, M.M.; Caponio, D.; Dan, X.; et al. Mitophagy inhibits amyloid-beta and tau pathology and reverses cognitive deficits in models of Alzheimer's disease. Nat. Neurosci. 2019, 22, 401-412. [CrossRef] [PubMed]

297. Hong, M.; Zhukareva, V.; Vogelsberg-Ragaglia, V.; Wszolek, Z.; Reed, L.; Miller, B.I.; Geschwind, D.H.; Bird, T.D.; McKeel, D.; Goate, A.; et al. Mutation-specific functional impairments in distinct Tau isoforms of hereditary FTDP-17. Science 1998, 282, 1914-1917. [CrossRef]

298. Gauthier-Kemper, A.; Weissmann, C.; Golovyashkina, N.; Sebo-Lemke, Z.; Drewes, G.; Gerke, V.; Heinisch, J.J.; Brandt, R. The frontotemporal dementia mutation R406W blocks tau's interaction with the membrane in an annexin A2-dependent manner. J. Cell Biol. 2011, 192, 647-661. [CrossRef] [PubMed]

299. Bodea, L.G.; Eckert, A.; Ittner, L.M.; Piguet, O.; Gotz, J. Tau physiology and pathomechanisms in frontotemporal lobar degeneration. J. Neurochem. 2016, 138, 71-94. [CrossRef]

300. Cummins, N.; Tweedie, A.; Zuryn, S.; Bertran-Gonzalez, J.; Gotz, J. Disease-associated tau impairs mitophagy by inhibiting Parkin translocation to mitochondria. EMBO J. 2019, 38. [CrossRef]

301. Cho, I.; Song, H.O.; Cho, J.H. Mitochondrial Uncoupling Attenuates Age-Dependent Neurodegeneration in C. elegans. Mol. Cells 2017, 40, 864-870. [CrossRef]

302. Zheng, H.; Yuan, C.; Zhang, H.; Chen, Y. The tissue- and developmental stage-specific involvement of autophagy genes in aggrephagy. Autophagy 2020, 16, 589-599. [CrossRef]

303. Jeong, H.; Then, F.; Melia, T.J., Jr.; Mazzulli, J.R.; Cui, L.; Savas, J.N.; Voisine, C.; Paganetti, P.; Tanese, N.; Hart, A.C.; et al. Acetylation targets mutant huntingtin to autophagosomes for degradation. Cell 2009, 137, 60-72. [CrossRef] [PubMed]

304. Baar, E.L.; Carbajal, K.A.; Ong, I.M.; Lamming, D.W. Sex- and tissue-specific changes in mTOR signaling with age in C57BL/6J mice. Aging Cell 2016, 15, 155-166. [CrossRef] [PubMed]

305. Ho, T.T.; Warr, M.R.; Adelman, E.R.; Lansinger, O.M.; Flach, J.; Verovskaya, E.V.; Figueroa, M.E.; Passegue, E. Autophagy maintains the metabolism and function of young and old stem cells. Nature 2017, 543, 205-210. [CrossRef] [PubMed]

306. Del Roso, A.; Vittorini, S.; Cavallini, G.; Donati, A.; Gori, Z.; Masini, M.; Pollera, M.; Bergamini, E. Ageing-related changes in the in vivo function of rat liver macroautophagy and proteolysis. Exp. Gerontol. 2003, 38, 519-527. [CrossRef]

307. Hughes, A.L.; Gottschling, D.E. An early age increase in vacuolar pH limits mitochondrial function and lifespan in yeast. Nature 2012, 492, 261-265. [CrossRef]

308. Maday, S.; Holzbaur, E.L. Autophagosome assembly and cargo capture in the distal axon. Autophagy 2012, 8, 858-860. [CrossRef]

309. Fonseca, R.; Vabulas, R.M.; Hartl, F.U.; Bonhoeffer, T.; Nagerl, U.V. A balance of protein synthesis and proteasome-dependent degradation determines the maintenance of LTP. Neuron 2006, 52, 239-245. [CrossRef]

310. Karpova, A.; Mikhaylova, M.; Thomas, U.; Knopfel, T.; Behnisch, T. Involvement of protein synthesis and degradation in long-term potentiation of Schaffer collateral CA1 synapses. J. Neurosci. 2006, 26, 4949-4955. [CrossRef] [PubMed]

311. Li, Q.; Korte, M.; Sajikumar, S. Ubiquitin-Proteasome System Inhibition Promotes Long-Term Depression and Synaptic Tagging/Capture. Cereb Cortex 2016, 26, 2541-2548. [CrossRef] [PubMed] 